\title{
Joining of $\mathrm{C}_{\mathbf{f}} / \mathrm{SiC}$ Ceramic Matrix Composites: A Review
}

\author{
Keqiang Zhang, ${ }^{1}$ Lu Zhang, ${ }^{1}$ Rujie He $\mathbb{D}^{1},{ }^{1}$ Kaiyu Wang, ${ }^{2}$ Kai Wei $\mathbb{D}^{,}{ }^{2}$ and Bing Zhang ${ }^{3}$ \\ ${ }^{1}$ Institute of Advanced Structure Technology, Beijing Institute of Technology, Beijing 100081, China \\ ${ }^{2}$ State Key Laboratory of Advanced Design and Manufacturing for Vehicle Body, Hunan University, Changsha 410082, China \\ ${ }^{3}$ Bristol Composites Institute (ACCIS), University of Bristol, Queen's Building, University Walk, Bristol BS8 1TR, UK \\ Correspondence should be addressed to Rujie He; herujie@bit.edu.cn
}

Received 1 March 2018; Revised 20 June 2018; Accepted 19 July 2018; Published 4 October 2018

Academic Editor: Mikhael Bechelany

Copyright (c) 2018 Keqiang Zhang et al. This is an open access article distributed under the Creative Commons Attribution License, which permits unrestricted use, distribution, and reproduction in any medium, provided the original work is properly cited.

\begin{abstract}
Carbon fiber-reinforced silicon carbide $\left(\mathrm{C}_{\mathrm{f}} / \mathrm{SiC}\right)$ ceramic matrix composites have promising engineering applications in many fields, and they are usually geometrically complex in shape and always need to join with other materials to form a certain engineering part. Up to date, various joining technologies of $\mathrm{C}_{\mathrm{f}} / \mathrm{SiC}$ composites are reported, including the joining of $\mathrm{C}_{\mathrm{f}} / \mathrm{SiC}$ $\mathrm{C}_{\mathrm{f}} / \mathrm{SiC}$ and $\mathrm{C}_{\mathrm{f}} / \mathrm{SiC}$-metal. In this paper, a systematic review of the joining of $\mathrm{C}_{\mathrm{f}} / \mathrm{SiC}$ composites is conducted, and the aim of this paper is to provide some reference for researchers working on this field.
\end{abstract}

\section{Introduction}

With the rapid development of high-tech in aerospace and other industry fields, the demands for new materials, which can work in extreme harsh working environment of high temperatures, are growing. The needs for better efficiency and higher thrust-to-weight ratio promote the development of advanced materials at high temperatures, such as superalloys [1-3], ceramics [4-6], composites [7-10], and so on. Among these advanced materials, ceramic matrix composites (CMCs) are drawn great attentions for their engineering applications under extreme conditions because they can maintain low density, high strength, wear resistance, oxidation resistance, thermal shock resistance, corrosion resistance, and some other functions together [11].

Carbon fiber-reinforced silicon carbide $\left(\mathrm{C}_{\mathrm{f}} / \mathrm{SiC}\right)$ ceramic matrix composites, one of the most famous CMCs, are becoming the most promising candidates for hightemperature structural applications (as illustrated in Figure 1), such as sharp leading edges, nose cones, aeronautic jet engines, thermal protection systems for reusable atmosphere reentry vehicles $[12,13]$, as well as optical components [14] and nuclear fusion/fission reactors $[15,16]$, owing to their relatively low density $\left(\sim 2 \mathrm{~g} / \mathrm{cm}^{3}\right)$, high thermal conductivity $(\sim 67 \mathrm{~W} /(\mathrm{m} \cdot \mathrm{K}))$, high strength $(300-800 \mathrm{MPa})$ [17-19], low coefficient of thermal expansion (CTE, 3.0-3.1 $\times 10^{-6} \cdot \mathrm{K}^{-1}$ ), especially good stability and excellent oxidation and creep resistance at elevated temperatures $[13,21-23,25]$. In particular, $\mathrm{C}_{\mathrm{f}} / \mathrm{SiC}$ composites have shown significant improvements in fracture toughness and thermal shock resistance. These improvements in mechanical properties are dependent on the specific properties of the carbon fiber and the silicon carbide. According to the type of carbon fiber, it can be divided into $1 \mathrm{D} \mathrm{C}_{\mathrm{f}} / \mathrm{SiC}, 2 \mathrm{D} \mathrm{C} \mathrm{C}_{\mathrm{f}} / \mathrm{SiC}, 2.5 \mathrm{D} \mathrm{C} \mathrm{C}_{\mathrm{f}} / \mathrm{SiC}$, and $3 \mathrm{D} \mathrm{C} / \mathrm{SiC}$ and applied in different fields.

For aerospace applications, as reported by NASA, the $\mathrm{X}-37 \mathrm{~B}$ and $\mathrm{X}-38$ aircrafts employed a large number of $\mathrm{C}_{\mathrm{f}} / \mathrm{SiC}$ composites in their nose cone [25], leading edge wing and engine components $[11,26,27,29]$. For nuclear applications, $\mathrm{C}_{\mathrm{f}} / \mathrm{SiC}$ composites are used as the cladding materials in pressurized water reactors and flow channel insert materials in thermonuclear fusion reactors $[29,30,32]$. In most cases, typically, $\mathrm{C}_{\mathrm{f}} / \mathrm{SiC}$ composite components are usually geometrically complex in shape and always need to join with other materials to form a certain engineering part. However, unfortunately, due to their poor machinability and toughness, $\mathrm{C}_{\mathrm{f}} / \mathrm{SiC}$ composites lack good processing performance like metal material and thus cannot be processed into complex-shaped components by forging, extrusion molding, and other traditional methods. It is very difficult to produce 


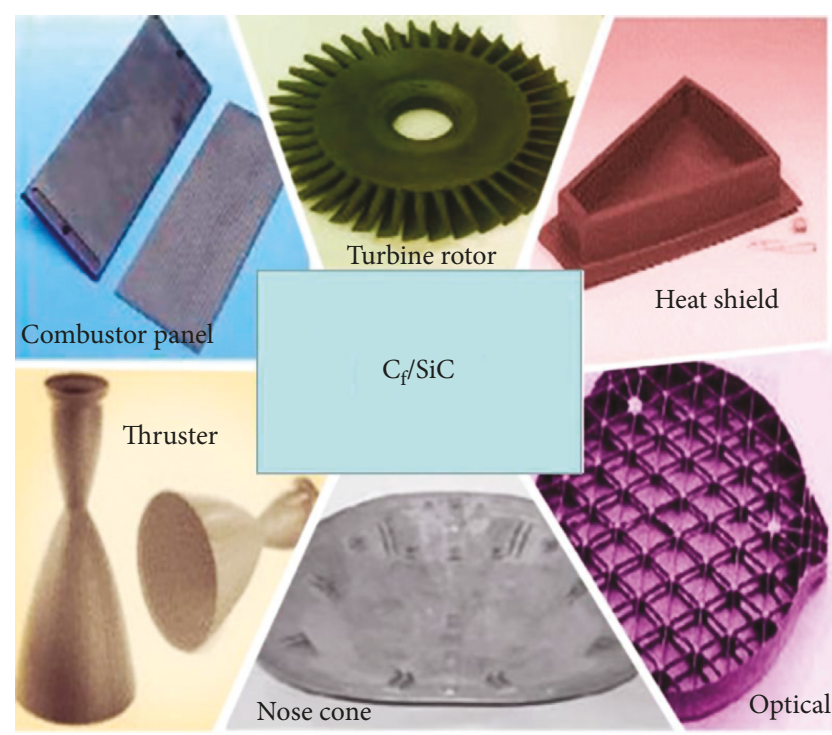

FIgURE 1: Various engineering applications of $\mathrm{C}_{\mathrm{f}} / \mathrm{SiC}$ composites.

large-size $\mathrm{C}_{\mathrm{f}} / \mathrm{SiC}$ composite components with complex shapes, resulting in they must be joined with themselves or other materials by appropriate joining technologies $[32-34,37]$. There have been numerous reports on the joining of $\mathrm{C}_{\mathrm{f}} / \mathrm{SiC}$ composites in the past two decades, including self-joining of $\mathrm{C}_{\mathrm{f}} / \mathrm{SiC}$ composites $[36,37,39]$, and joining of $\mathrm{C}_{\mathrm{f}} / \mathrm{SiC}$ composite to dissimilar materials, such as $\mathrm{Ti}[39,40], \mathrm{Nb}[41,42,45], \mathrm{Ni}[44,45,48]$, TiAl alloys [47], and so on.

$\mathrm{Up}$ to date, various joining technologies of $\mathrm{C}_{\mathrm{f}} / \mathrm{SiC}$ composites are reported, including the joining of $\mathrm{C}_{\mathrm{f}} / \mathrm{SiC}$ $\mathrm{C}_{\mathrm{f}} / \mathrm{SiC}$ and $\mathrm{C}_{\mathrm{f}} / \mathrm{SiC}$-metal. Table 1 lists commonly used joining technologies, such as direct bonding of $\mathrm{C}_{\mathrm{f}} / \mathrm{SiC}$ $\mathrm{C}_{\mathrm{f}} / \mathrm{SiC}$, indirect bonding of $\mathrm{C}_{\mathrm{f}} / \mathrm{SiC}-\mathrm{C}_{\mathrm{f}} / \mathrm{SiC}$, brazing of $\mathrm{C}_{\mathrm{f}} / \mathrm{SiC}$ metal, diffusion bonding of $\mathrm{C}_{\mathrm{f}} / \mathrm{SiC}$-metal, online liquid infiltration of $\mathrm{C}_{\mathrm{f}} / \mathrm{SiC}$-metal, ultrasonic-assisted joining of $\mathrm{C}_{\mathrm{f}} / \mathrm{SiC}$-metal, and electric-assisted joining of $\mathrm{C}_{\mathrm{f}} / \mathrm{SiC}$-metal. To the best knowledge of the authors, however, there has been no systematic summary of the joining of $\mathrm{C}_{\mathrm{f} / \mathrm{SiC}}$ composites. Therefore, we herein conduct a systematic review of the joining of $\mathrm{C}_{\mathrm{f}} / \mathrm{SiC}$ composites, and the aim of this paper is to provide some reference for researchers working on this field.

\section{Self-Joining of $\mathrm{C}_{\mathrm{f}} / \mathrm{SiC}$ Composites}

In some conditions, in order to obtain large size and complex-shaped $\mathrm{C}_{\mathrm{f}} / \mathrm{SiC}$ composite components, it is necessary that $\mathrm{C}_{\mathrm{f}} / \mathrm{SiC}$ composites should be joined with $\mathrm{C}_{\mathrm{f}} / \mathrm{SiC}$ composites themselves, named as "self-joining." There have been many reports about the self-joining of $\mathrm{C}_{\mathrm{f}} / \mathrm{SiC}$ composites in the last decades, usually including direct bonding and indirect bonding method.

2.1. Direct Bonding. Direct bonding method is a self-joining of $\mathrm{C}_{\mathrm{f}} / \mathrm{SiC}$ composites by solid-phase diffusion without any other materials (Figure 2(a)). As reported in previous papers,
TABLE 1: Commonly used joining methods of $\mathrm{C}_{\mathrm{f}} / \mathrm{SiC}$ composites.

\begin{tabular}{lc}
\hline Joining materials & Joining methods \\
\hline $\mathrm{C}_{\mathrm{f}} / \mathrm{SiC}-\mathrm{C}_{\mathrm{f}} / \mathrm{SiC}$ & $\begin{array}{c}\text { Direct bonding } \\
\text { Indirect bonding }\end{array}$ \\
\hline & Brazing \\
$\mathrm{C}_{\mathrm{f}} / \mathrm{SiC}-$ metal & Diffusion bonding \\
& Online liquid infiltration \\
& Ultrasonic-assisted joining \\
& Electric-assisted joining \\
\hline
\end{tabular}

the main procedure of direct bonding usually includes three procedures: (1) plastic deformation, (2) diffusion, and (3) creep. Plastic deformation occurs on the interface because of heat and pressure; diffusion includes surface diffusion, bulk diffusion, grain boundary diffusion, and interfacial diffusion to achieve $\mathrm{C}_{\mathrm{f}} / \mathrm{SiC}$ bonding. Creep refers to the permanent movement or deformation of metal.

However, the bonding strength of the directly joined $\mathrm{C}_{\mathrm{f}} / \mathrm{SiC}$ composite is usually very low because a strong bonding of $\mathrm{C}_{\mathrm{f}} / \mathrm{SiC}$ composite is difficult to obtain without any other transition phases and because the diffusion between $\mathrm{C}_{\mathrm{f}} / \mathrm{SiC}$ composites is not easy owing to the strong covalent bond and the poor deformation ability of the $\mathrm{SiC}$ in the composites. Rizzo et al. [48] reported that a CVD-SiC coated $\mathrm{C}_{\mathrm{f}} / \mathrm{SiC}$ composite was directly joined to its counterparts using spark plasma sintering (SPS) technology. The results showed that the cracks in the CVD-SiC coating were visible among the interface and propagated from the $\mathrm{SiC}$ coating through the joint area (as is shown in Figure 3), due to the CTE mismatch between $\mathrm{SiC}$ coating and $\mathrm{C}_{\mathrm{f}} / \mathrm{SiC}$ substrate (as is shown in Table 2), and the apparent shear strength was as low as $5.6 \mathrm{MPa}$.

Therefore, direct bonding method is merely used owing to the low bonding strength. However, it is still very promising for direct bonding method of $\mathrm{C}_{\mathrm{f}} / \mathrm{SiC}$ composites, especially for extreme applications where it demands to avoid a second material.

2.2. Indirect Bonding. It is well known that it is very difficult to form diffusion between $\mathrm{C}_{\mathrm{f}} / \mathrm{SiC}$ composites owing to the strong covalent bond and the poor deformation ability of the $\mathrm{SiC}$ in $\mathrm{C}_{\mathrm{f}} / \mathrm{SiC}$ composites, thus resulting in a weak bonding strength of direct bonding joint (Figure 2(b)). Therefore, second-phase materials with plastic deformability, such as Ag-Cu-Ti [30, 49], Ti-Zr-Be [50], Ni [31, 51, 52, 55], calciaalumina (CA) glass-ceramic [54], $\mathrm{Ti}_{3} \mathrm{SiC}_{2}[16,36,55,56]$ and Si resin [57], and $\mathrm{MoSi}_{2}$ [58], were widely reported to be used for the joining of $\mathrm{C}_{\mathrm{f}} / \mathrm{SiC}$ composites. These kinds of joining are known as indirect bonding method, always including using metal filler or nonmetal filler.

2.2.1. Metal Fillers. This method means that $\mathrm{C}_{\mathrm{f}} / \mathrm{SiC}$ composites are bonded with $\mathrm{C}_{\mathrm{f}} / \mathrm{SiC}$ composites using metal fillers, such as pure metal or alloys. Table 3 lists some typical reports on the self-joining of $\mathrm{C}_{\mathrm{f}} / \mathrm{SiC}$ composites using metal fillers. 


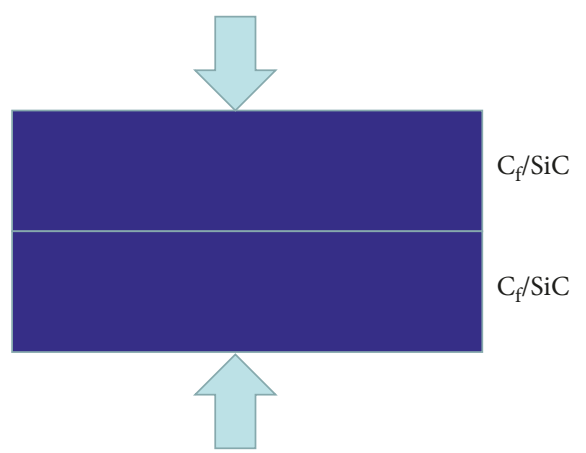

(a)

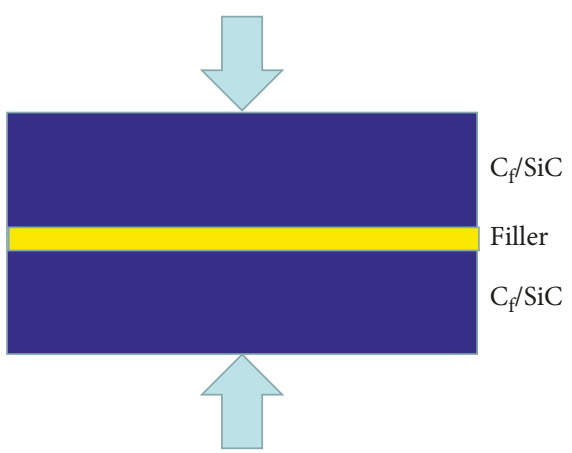

(b)

Figure 2: The diagram of (a) direct bonding and (b) indirect bonding.

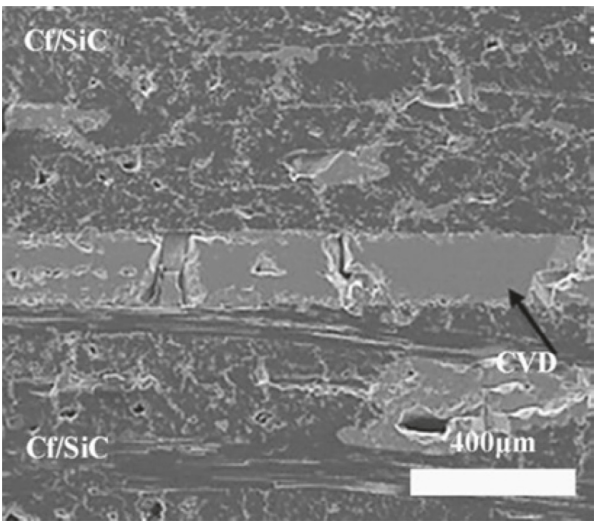

FIGURE 3: Scanning electron microscopy of polished cross sections of $\mathrm{C}_{\mathrm{f}} / \mathrm{SiC}$ specimens joined by SPS: direct bonding [48].

TABLE 2: CTE of typical materials (room temperature).

\begin{tabular}{lc}
\hline Materials & $\mathrm{CTE}\left(\times 10^{-6} \cdot \mathrm{K}^{-1}\right)$ \\
\hline $\mathrm{C}_{\mathrm{f}} / \mathrm{SiC}$ & $3.0-3.1$ \\
$\mathrm{Ti}$ & 8 \\
$\mathrm{Al}$ & 23.5 \\
$\mathrm{Cu}$ & 16.5 \\
$\mathrm{Ni}$ & 13 \\
$\mathrm{Ag}$ & 19.5 \\
$\mathrm{Nb}$ & 7.2 \\
$\mathrm{Mo}$ & 5.2 \\
$\mathrm{~W}$ & 4.43 \\
$\mathrm{Zr}$ & 5.2 \\
$\mathrm{Co}$ & 6.8 \\
$\mathrm{Ta}$ & 6.7 \\
$\mathrm{C}$ & 1.5 \\
$\mathrm{TiAl}$ & 10.8 \\
$\mathrm{CrMo}$ & 12.5 \\
$\mathrm{SiC}$ & 4.8 \\
$\mathrm{Ti}{ }_{3} \mathrm{SiC}$ & 9.1 \\
$\mathrm{TiC}$ & 7.4 \\
\hline
\end{tabular}

The low-temperature active filler is a relatively mature technology and widely used in $\mathrm{C}_{\mathrm{f}} / \mathrm{SiC}$ composites; however, the joint phase such as $\mathrm{Ag}, \mathrm{Cu}$, and other metals, usually with low melting point, leads to poor high-temperature strength and oxidation resistance. Therefore, $\mathrm{C}_{\mathrm{f}} / \mathrm{SiC}$ composites joined by metal fillers can only be used in low-temperature environment $\left(<500^{\circ} \mathrm{C}\right)$.

Liu et al. [30] reported the $\mathrm{C}_{\mathrm{f}} / \mathrm{SiC}$ composites joined by ternary Ag-35.25 wt\% Cu-1.75 wt\% $\mathrm{Ti}$ and demonstrated that the mechanical strength decreased with the increase in temperature owing to the softening of filler. The flexural strength decreased to $46 \%$ and $26 \%$ at 300 and $500^{\circ} \mathrm{C}$ compared with that at room temperature, respectively. Stefano et al. [48] fabricated $\mathrm{C}_{\mathrm{f}} / \mathrm{SiC}-\mathrm{Ti}-\mathrm{C}_{\mathrm{f}} / \mathrm{SiC}$ sandwich by SPS and used pure Ti foils as filler. They also found that a TiSi-C-based phase $\left(\mathrm{Ti}_{3} \mathrm{SiC}_{2}\right.$, as is shown in Figure 4) was the main reaction product, usually induced to strength decrease.

High-temperature metal fillers, such as $\mathrm{Ni}$ and its alloys, are reported and found to greatly improve the hightemperature resistance of the joint [61, 62]. Cheng $[51,52,55]$ developed a novel joining process to join the $2 \mathrm{D} / 3 \mathrm{D} \mathrm{C} / \mathrm{SiC}$ composites. Porous $\mathrm{C}_{\mathrm{f}} / \mathrm{SiC}$ composites were fabricated through chemical vapor infiltration (CVI) process, and $\mathrm{Ni}$ alloy was used to join the $\mathrm{C}_{\mathrm{f}} / \mathrm{SiC}$ composites together. Figure 5 shows the diagram of this joining process. Because the Ni alloy had a favorable wettability with $\mathrm{C}_{\mathrm{f}} / \mathrm{SiC}$ composites, melted $\mathrm{Ni}$ alloy easily infiltrated into the pores among $\mathrm{C}_{\mathrm{f}} / \mathrm{SiC}$ composites. Hence, the contact surface between $\mathrm{Ni}$ alloy and $\mathrm{C}_{\mathrm{f}} / \mathrm{SiC}$ composites matrix was greatly increased, thereby improved the bonding strength. Besides, $\mathrm{Ni}$ alloy had a higher melting point; hence, the joint was expected to be used at high temperatures $\left(>1000^{\circ} \mathrm{C}\right)$.

Table 4 lists some typical reports on the self-joining of $\mathrm{C}_{\mathrm{f}} / \mathrm{SiC}$ composites with high-temperature fillers (Ni alloy). As a nontraditional joining method, the self-joining process using $\mathrm{Ni}$ alloy is usually carried out during composite preparation procedure, and the damage is minimal. And after the joining process, an afterward CVD process is conducted, which not only densify the porous composites but also provides antioxidation coating for the matrix and the joint.

2.2.2. Nonmetal Fillers. Nonmetal fillers, such as MAX ceramic [16, 36, 55, 56, 63], ceramic precursors [64], Si resin [57], and $\mathrm{MoSi}_{2}$ [58], are also reported to be used in the selfjoining of $\mathrm{C}_{\mathrm{f}} / \mathrm{SiC}$ composites (as listed in Table 5).

MAX phase ceramics are reported to exhibit not only high-temperature performance, thermal shock resistance, 
TABLE 3: Self-joining of $\mathrm{C}_{\mathrm{f}} / \mathrm{SiC}$ composites using metal filler ( $\mathrm{SS}=$ shear strength).

\begin{tabular}{|c|c|c|c|c|c|}
\hline CMCs & Basic information & Metal filler & Process parameters & Bend strength (MPa) & Ref. \\
\hline $\mathrm{C}_{\mathrm{f}} / \mathrm{SiC}$ & CVD-SiC & $\mathrm{Ti}$ & $1700^{\circ} \mathrm{C}, 3 \mathrm{~min}, 60 \mathrm{MPa}$, vacuum & $24.6(\mathrm{SS})$ & [48] \\
\hline $\mathrm{C}_{\mathrm{f}} / \mathrm{SiC}$ & $3 \mathrm{D}, 10.0$ vol. $\%$, PIP & $\mathrm{Cu}-\mathrm{Au}-\mathrm{Pd}-\mathrm{V}$ & $1170^{\circ} \mathrm{C}, 10 \min , 1.5 \times 10^{-3} \mathrm{~Pa}$ & 135 & [59] \\
\hline $\mathrm{C}_{\mathrm{f}} / \mathrm{SiC}$ & $3 \mathrm{D}$ & Pd-Co-V & $1250^{\circ} \mathrm{C}, 20 \mathrm{~min}, 3.0-7.0 \times 10^{-3} \mathrm{~Pa}$ & - & [60] \\
\hline $\mathrm{C}_{\mathrm{f}} / \mathrm{SiC}$ & 3D, PIP, 10.0 vol. $\%$ & $\mathrm{Cu}-\mathrm{Pd}-\mathrm{V}$ & $1170^{\circ} \mathrm{C}, 10 \mathrm{~min}, 3.0-7.0 \times 10^{-3} \mathrm{~Pa}$ & 128 & [61] \\
\hline
\end{tabular}

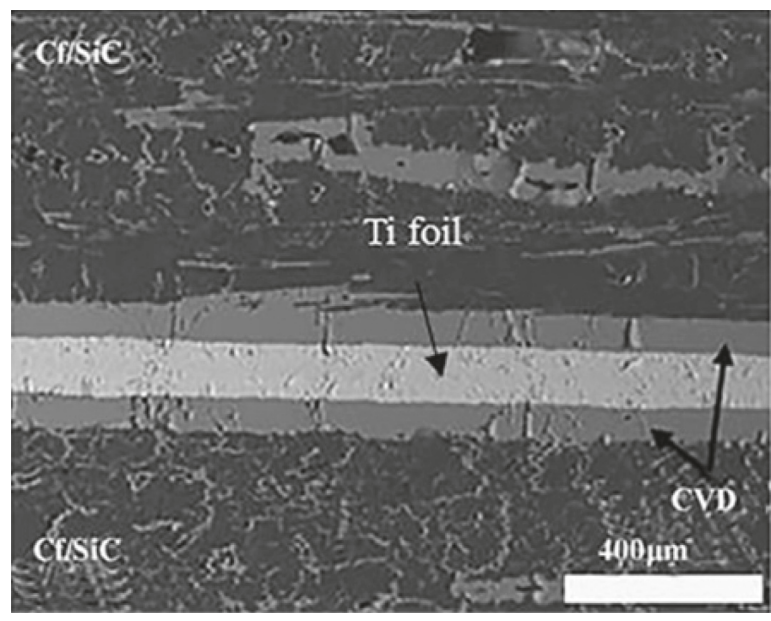

(a)

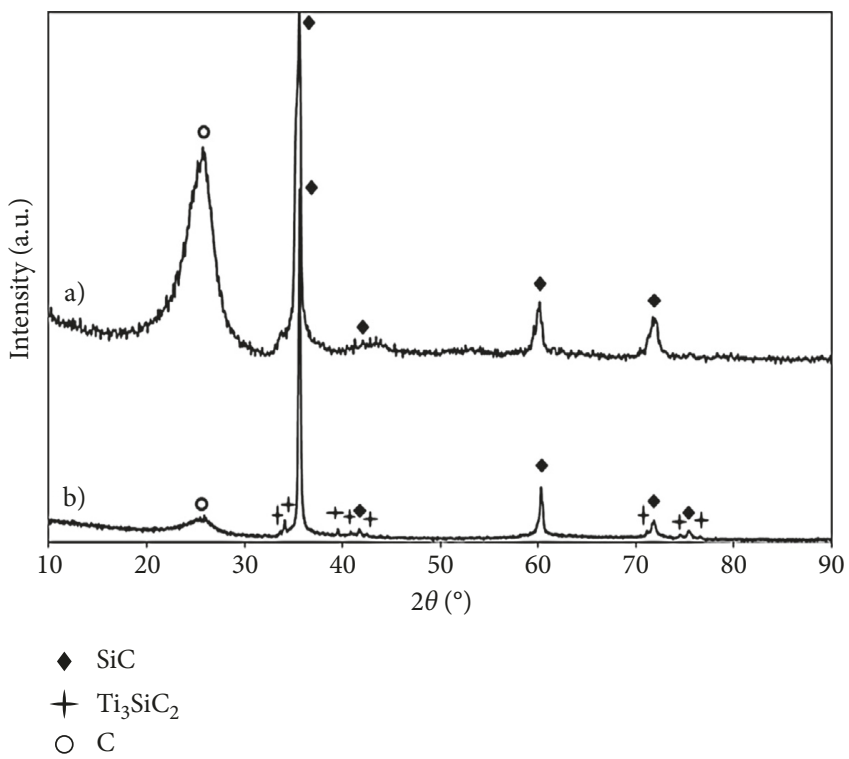

(b)

FIGURE 4: (a) Backscattered electron images of polished cross sections and (b) micro-XRD on the fracture surfaces of $\mathrm{C}_{\mathrm{f}} / \mathrm{SiC}$ joined by $\mathrm{SPS}$ with Ti foil [48].

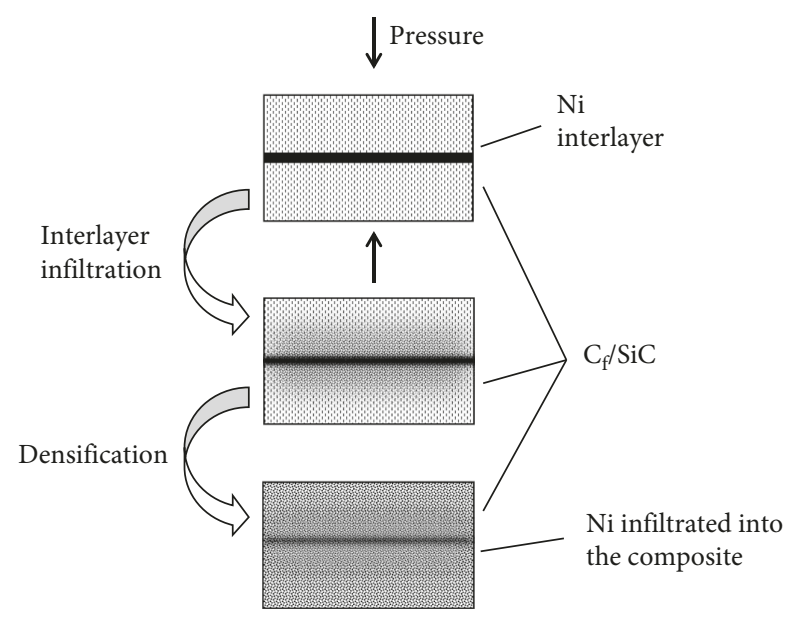

FIGURE 5: The diagram of self-joining using Ni alloy.

and wear resistance but also a good plastic deformation capacity. Among various $\mathrm{MAX}$ phase ceramics, $\mathrm{Ti}_{3} \mathrm{SiC}_{2}$ presents a suitable wettability and CTE toward $\mathrm{C}_{\mathrm{f}} / \mathrm{SiC}$ composites matrix (as is shown in Table 2) and is thus believed to be a promising candidate for the self-joining of $\mathrm{C}_{\mathrm{f}} / \mathrm{SiC}$ composites $[16,55,56]$. Dong et al. [55] used $\mathrm{Ti}_{3} \mathrm{SiC}_{2}$ as the nonmetal filler to join $\mathrm{C}_{\mathrm{f}} / \mathrm{SiC}$ composite together through hot pressing. The shear strength of the joint was reported as high as $110.4 \mathrm{MPa}\left(56.7 \%\right.$ of the $\mathrm{C}_{\mathrm{f}} / \mathrm{SiC}$ composite matrix). Chemical reactions took place at the interface between $\mathrm{Ti}_{3} \mathrm{SiC}_{2}$ and $\mathrm{C}_{\mathrm{f}} / \mathrm{SiC}$, and residual thermal stress was investigated. The phase compositions of the fracture surfaces for the $\mathrm{C}_{\mathrm{f}} / \mathrm{SiC}$ joints joined at various temperatures were also analyzed by XRD (as is shown in Figure 6). In addition, the fracture behavior of joining interface and brazing application was explored in previous articles $[9,65,66,69]$. Interfacial reactions can affect the formation of a joint from the onset of bonding through the development of equilibrated microstructure and to the optimization of the mechanical properties. It has been demonstrated that an adequate joining interface could lead to improvements of the composite wettability by $\mathrm{C}_{\mathrm{f}} / \mathrm{SiC}$ [39].

Besides, ceramic precursors are also used as nonmetal fillers for the self-joining of $\mathrm{C}_{\mathrm{f}} / \mathrm{SiC}$ composites. The ceramic precursor is transformed into amorphous ceramic at a certain temperature, and the composition and structure of the precursor are similar to those of the composite matrix. At the same time, the pyrolysis products are directly bonded with the composite matrix by chemical bonds. The thermodynamic properties of the joining layer obtained by this method are similar to those of the matrix [64]. And it has good compatibility with the composite matrix. Therefore, 
TABLE 4: Self-joining of $\mathrm{C}_{\mathrm{f}} / \mathrm{SiC}$ composites with high-temperature fillers.

\begin{tabular}{lcccr}
\hline $\mathrm{CMCs}$ & Basic information & Joining material & Process parameters & Bend strength $(\mathrm{MPa})$ \\
\hline $\mathrm{C}_{\mathrm{f}} / \mathrm{SiC}$ & $3 \mathrm{D}, \mathrm{CVI}$ & $\mathrm{Ni}$ alloy & $1300^{\circ} \mathrm{C}, 45 \mathrm{~min}, 20 \mathrm{MPa}$, vacuum & 260.3 \\
$\mathrm{C}_{\mathrm{f}} / \mathrm{SiC}$ & $2 \mathrm{D}, \mathrm{CVI}$ & $\mathrm{Ni}$ alloy & $1300^{\circ} \mathrm{C}, 45 \mathrm{~min}, 20 \mathrm{MPa}$, vacuum & {$[52]$} \\
$\mathrm{C}_{\mathrm{f}} / \mathrm{SiC}$ & $2 \mathrm{D}, \mathrm{CVI}$ & $\mathrm{Ni}$ alloy & $1300^{\circ} \mathrm{C}, 15 \mathrm{MPa}$, vacuum & {$[51]$} \\
\hline
\end{tabular}

TABLE 5: Self-joining of $\mathrm{C}_{\mathrm{f}} / \mathrm{SiC}$ composites using inorganic filler (BS = bend strength).

\begin{tabular}{lcccr}
\hline $\mathrm{CMCs}$ & Basic information & Joining material & Process parameters & Shear strength $(\mathrm{MPa})$ \\
\hline $\mathrm{C}_{\mathrm{f}} / \mathrm{SiC}$ & $2 \mathrm{D}, \mathrm{CVI}, 2.05 \mathrm{~g} / \mathrm{cm}^{3}, 40 \mathrm{MPa}$ & $\mathrm{Ti}_{3} \mathrm{SiC}_{2}$ & $1600^{\circ} \mathrm{C}, 30 \mathrm{~min}, 20-40 \mathrm{MPa}, \mathrm{Ar}$ & $110.4(\mathrm{BS})$ \\
$\mathrm{C}_{\mathrm{f}} / \mathrm{SiC}$ & $3 \mathrm{D}, \mathrm{CVI}$ & $\mathrm{PSZ}$ & $1300^{\circ} \mathrm{C}, \mathrm{N}_{2}$ & 29.6 \\
$\mathrm{C}_{\mathrm{f}} / \mathrm{SiC}$ & $3 \mathrm{D}, \mathrm{PIP}, 1.9 \mathrm{~g} / \mathrm{cm}^{3}$ & $\mathrm{Si} \mathrm{resin}$ & $1400^{\circ} \mathrm{C}, 5 \mathrm{~h}, \mathrm{Ar}$ & {$[64]$} \\
$\mathrm{C}_{\mathrm{f}} / \mathrm{SiC}$ & $2 \mathrm{D}, \mathrm{CVI}, 1.7-2.2 \mathrm{~g} / \mathrm{cm}^{3}$ & $\mathrm{MoSi}_{2} / \mathrm{Si}$ & $1450^{\circ} \mathrm{C}, 5 \mathrm{~min}, \mathrm{Ar}$ & 3.51 \\
\hline
\end{tabular}

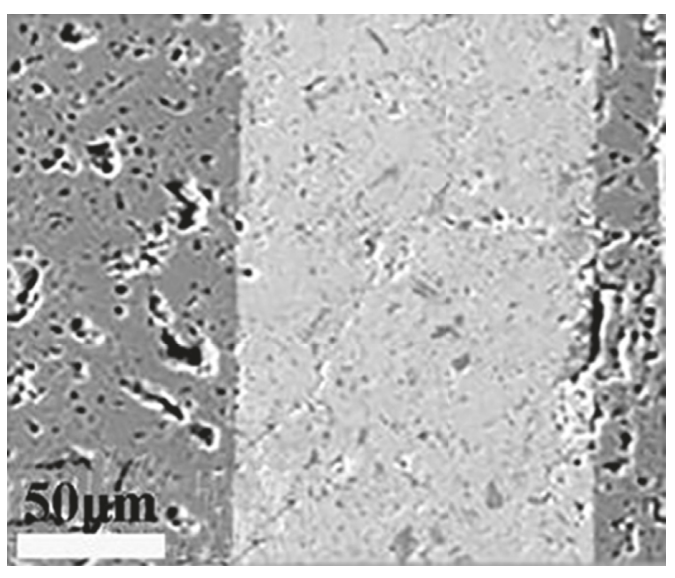

(a)

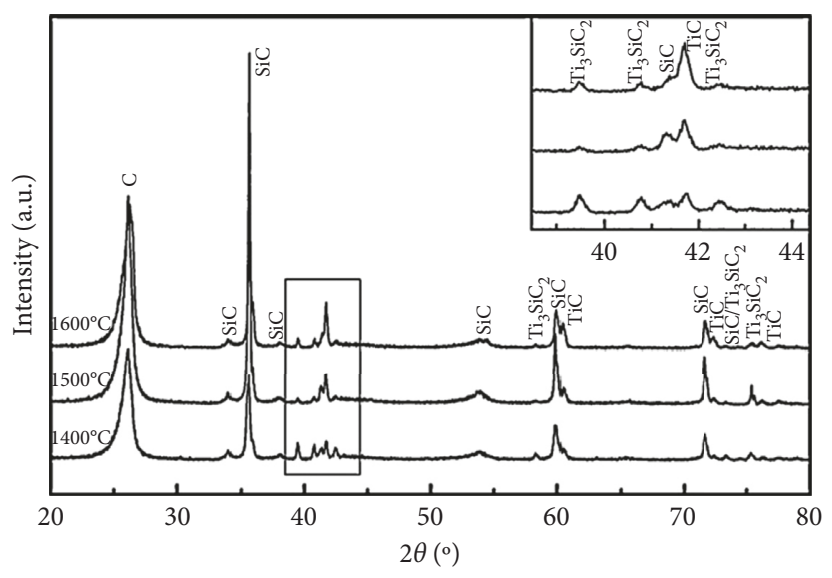

(b)

Figure 6: (a) The backscattered electron images and (b) XRD patterns of the fracture surfaces of the $\mathrm{C}_{\mathrm{f}} / \mathrm{SiC}$ joints [55].

the joint exhibits good mechanical strength. Previous reports showed that $\mathrm{C}_{\mathrm{f}} / \mathrm{SiC}$ composite was joined using $\mathrm{Si}-\mathrm{O}-\mathrm{C}$ ceramic precursor as filler [57].

$\mathrm{Si}$ resin is transformed into $\mathrm{Si}-\mathrm{O}-\mathrm{C}$ ceramic at low temperature; the Si-O-C ceramics infiltrating into the substrate improve the filler contact with the substrate closely and increase the connection area. Moreover, the Si-O-C ceramics infiltrating into the pits can form tiny "pins," thus increasing the shear strength of the joints. Gianchandani et al. [58] reported that a $\mathrm{MoSi}_{2} / \mathrm{Si}$ composite obtained in situ by reaction of silicon and molybdenum at $1450^{\circ} \mathrm{C}$ in Ar flow is proposed as pressure-less joining material for $\mathrm{C}_{\mathrm{f}} / \mathrm{SiC}$ composites.

To sum up, we can know that the application of nonmetal fillers method due to the phase consistency of joining material and matrix was similar, which not only avoid the CTE mismatch between the joining material and the matrix (CTE of typical materials is shown in Table 2) but also inhibit the adverse reactions of interface. It will be a very promising method in the future.

\section{Joining of $\mathrm{C}_{\mathrm{f}} / \mathrm{SiC}$ Composites to Metals}

In order to obtain large size and complex-shaped components, the joining of $\mathrm{C}_{\mathrm{f}} / \mathrm{SiC}$ composites to metals such as $\mathrm{Ti}$
[40], $\mathrm{Nb}[42,68,69], \mathrm{Ni}[70]$, and TiAl alloys [30, 46, 71] is necessary. Due to the differences in physical, chemical and mechanical properties between $\mathrm{C}_{\mathrm{f}} / \mathrm{SiC}$ composites and metals, there are several problems for the joining of $\mathrm{C}_{\mathrm{f}} / \mathrm{SiC}$ composites to metals: firstly, the chemical bonds of $\mathrm{C}_{\mathrm{f}} / \mathrm{SiC}$ composites are ionic bond and covalent bond and the valence state is stable, whereas metals mostly are metal bond and therefore it is difficult to wet the surface of $\mathrm{C}_{\mathrm{f}} / \mathrm{SiC}$ composites by metal [40]. Secondly, the CTE mismatch between metals and $\mathrm{C}_{\mathrm{f}} / \mathrm{SiC}$ composites is very large, which will produce residual stress at the joint interface; hence, cracks, pores, and other defects exist after cooling $[41,72,73]$. At last, a variety of chemical reactions occur in the interface, resulting in brittle compounds with high hardness, which usually is the reason for the brittle fracture of the joint during working [30].

At present, there are many technologies solving the above problems during the joining process. Brazing and diffusion bonding are the most commonly used methods. In addition, online liquid infiltration joining, ultrasonic-assisted joining, and electric-assisted field joining are also reported.

3.1. Brazing. Brazing is one of the earliest and most commonly used methods for joining CMCs to metals 


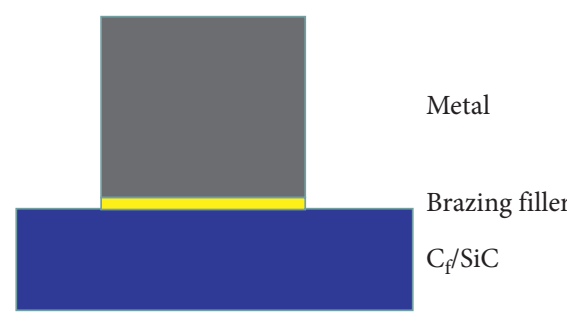

(a)

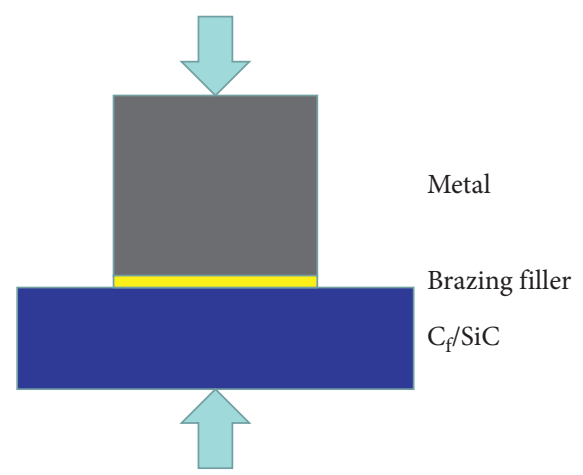

(b)

FIgURE 7: The schematic diagram of (a) brazing method and (b) diffusion bonding method.

(Figure 7(a)). It is divided into two kinds as follows: (1) metallizing the $\mathrm{C}_{\mathrm{f}} / \mathrm{SiC}$ composite surface and then brazing with ordinary brazing filler metals, usually known as indirect brazing, and (2) wetting CMCs surface directly using active metal, known as reactive brazing. Compared with indirect brazing, the scopes of application of reactive brazing are more extensive. Usually, metals and alloys with lower melting points are selected as the brazing fillers, and then the joint is heated to a certain temperature, which is higher than the melting point of brazing filler, and then brazing is conducted [74].

3.1.1. Low-Temperature Fillers. Low-temperature filler is a kind of metal with low melting point, such as $\mathrm{Ag}$ and $\mathrm{Cu}$, which can form brazing filler at lower temperature to realize the joining of metal. Due to the low joining temperature, the damage is low.

Brazing method is simple and convenient; however, the brazing filler is mainly active metal elements, so it is necessary to protect the active metal elements from oxidation. Once the active element is oxidized, it is difficult to react with $\mathrm{C}_{\mathrm{f}} / \mathrm{SiC}$ composites and to form a reliable joint; consequently, the joint strength is low. Therefore, brazing method is generally carried out in vacuum conditions or inert protective gases $[39,75]$. Feng et al. $[72,76]$ investigated the microstructural evolution and joint strength of between $\mathrm{TiAl}$ alloys and $\mathrm{C}_{\mathrm{f}} / \mathrm{SiC}$ composite via vacuum brazing using $\mathrm{Ag}-\mathrm{Cu}$ and $\mathrm{Ag}-\mathrm{Cu}-\mathrm{Ti}$ fillers. The diffusion of $\mathrm{Al}$ and Ti from TiAl to the matrix had an important effect on the structure and strength of joints. When active element Ti diffused into $\mathrm{C}_{\mathrm{f}} / \mathrm{SiC}$ composite, the formation of $\mathrm{AlCu}_{2} \mathrm{Ti}$ and $\mathrm{Ag}$ solid solution was detected with the dissolved $\mathrm{Ti}$ and $\mathrm{Al}$; moreover, $\mathrm{Ti}_{5} \mathrm{Si}_{3}$ phase and $\mathrm{TiC}$ also formed adjacent to the composite (as is shown in Figure 8). The maximum shear strength achieved $85 \mathrm{MPa}$ with the thickness of TiC layer of $4-5 \mu \mathrm{m}$. The fracture of the joint went through the $\mathrm{TiC}$ layer adjacent to its interface with the $\mathrm{Ag}$ solid solution and $\mathrm{TiC}$ bond layer.

As is shown in Table 6, Ag-Cu, Ag-Cu-Ti, and others are low-temperature fillers $\left(900^{\circ} \mathrm{C}\right)$ and have low yield strength and good deformation ability, which is helpful to alleviate the residual stress of the joint, thus increasing the shear strength of the joints.
3.1.2. High-Temperature Fillers. Ag-Cu-Ti alloys have good plastic deformation behaviors (as is shown in Table 7); nevertheless, they always have low melting points and can only be used in low-temperature environments $\left(<800^{\circ} \mathrm{C}\right)$. Once the temperature increased, the strength of the joint drops sharply. Therefore, it is necessary to develop suitable high-temperature brazing filler for high-temperature conditions.

Huang et al. [46] joined $\mathrm{C}_{\mathrm{f}} / \mathrm{SiC}$ composite to $\mathrm{TC}_{4}$ alloy using (Ti-Zr-Cu-Ni) and $\mathrm{W}$ powder as brazing fillers. Ti and $\mathrm{Zr}$ elements reacted with $\mathrm{C}, \mathrm{Cu}$, and $\mathrm{Ni}$ in the interlayer. As elements diffused to each other, a reaction layer was formed between the $\mathrm{C}_{\mathrm{f}} / \mathrm{SiC}$ composite and $\mathrm{TC}_{4}$ alloy. The brazing parameters had a significant effect on the interfacial reaction between $\mathrm{C}_{\mathrm{f}} / \mathrm{SiC}$ composite and joining material, which affected the shear strength of the joints. A continuous reaction layer adjacent to $\mathrm{C}_{\mathrm{f}} / \mathrm{SiC}$ composite and a diffusion layer near $\mathrm{TC}_{4}$ alloy can be clearly observed (Figures 9 and 10). The addition of appropriate $\mathrm{W}$ powder helped to relieve residual stress and improved the strength of the joints. The shear strength of the joint was $166 \mathrm{MPa}$ and $96 \mathrm{MPa}$ at room temperature and $800^{\circ} \mathrm{C}$, respectively. Therefore, the joint can be used under high temperature.

However, the effect of $\mathrm{W}$ powder on the residual stress was small and the residual stress was still high. Ti- $\mathrm{Zr}-\mathrm{Cu}-\mathrm{Ni}$ alloy and pure Ti metals were used as joining materials [30]; the molten Ti-Zr-Cu-Ni reacted with solid Ti in the liquidsolid reaction to form an in situ alloy. The effects of Ti contents on the strength of joints were explored. With the increase in the Ti content, more tearing ridges appeared in the fracture surfaces, which indicated that the fracture possessed more plasticity. When the Ti content reached up to $40 \%$, the shear strength of the joint reached up to $283 \mathrm{MPa}$, which was $79 \%$ higher than using $\mathrm{Ti}-\mathrm{Zr}-\mathrm{Cu}-\mathrm{Ni}$ alone. The main reason was that the metal Ti had better plasticity, and the proper addition was beneficial for improving the interfacial reaction between $\mathrm{C}_{\mathrm{f}} / \mathrm{SiC}$ composite and Ti-6Al-4V alloy.

There are many research studies using brazing method for joining $\mathrm{C}_{\mathrm{f}} / \mathrm{SiC}$ to metals as listed in Table 7. The lowexpansion material $(\mathrm{W})$, the soft metal $(\mathrm{Ni})$, and the hightemperature metal (Mo) as the reinforcing phase are added into the brazing filler, so that the CTE of the brazing filler is 


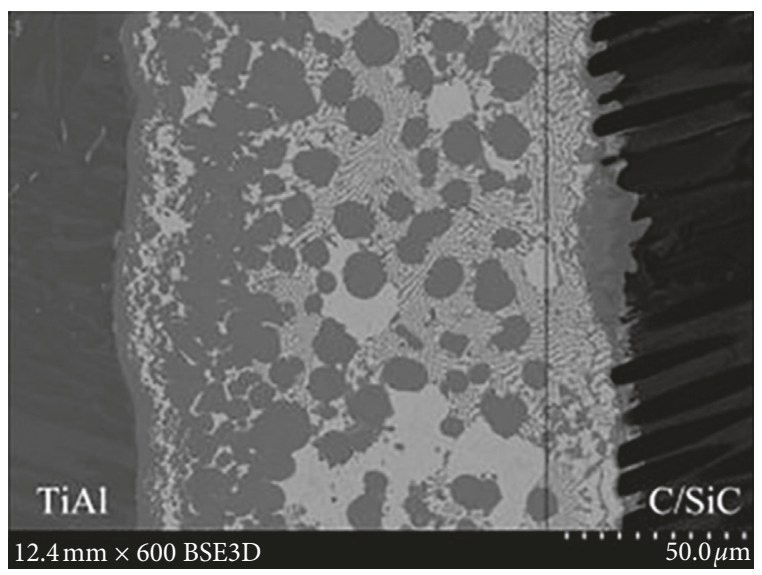

(a)

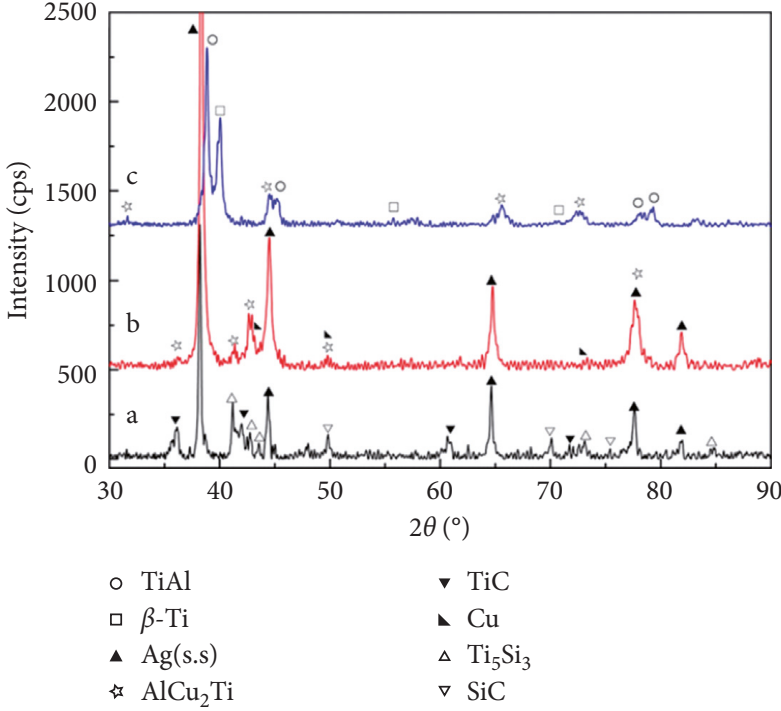

(b)

FIgUre 8: (a) Microstructures and (b) XRD patterns of the joint from $\mathrm{C} / \mathrm{SiC}$ composites to TiAl brazed at $900^{\circ} \mathrm{C}$ for $10 \mathrm{~min}[72]^{\text {. }}$

TABLE 6: Brazing of $\mathrm{C}_{\mathrm{f}} / \mathrm{SiC}$ composites to metals with low-temperature fillers.

\begin{tabular}{|c|c|c|c|c|c|c|}
\hline CMCs & Basic information & Metal & Brazing material & Process parameters & Shear strength $(\mathrm{MPa})$ & Ref. \\
\hline $\mathrm{C}_{\mathrm{f}} / \mathrm{SiC}$ & $3 \mathrm{D}, \mathrm{PIP}, 1.86 \mathrm{~g} / \mathrm{cm}^{3}$ & Ti Al alloys & $\mathrm{Ag}-\mathrm{Cu}$ & $900^{\circ} \mathrm{C}, 10 \mathrm{~min}, 5 \times 10^{-3} \mathrm{~Pa}$ & 85 & {$[72]$} \\
\hline $\mathrm{C}_{\mathrm{f}} / \mathrm{SiC}$ & $3 \mathrm{D}, \mathrm{CVI}$ & $\mathrm{TC}_{4}$ alloys & $\mathrm{Ag}-\mathrm{Cu}-\mathrm{Ti}$ & $900^{\circ} \mathrm{C}, 5 \mathrm{~min}, 10^{-4} \mathrm{~Pa}$ & 102 & [77] \\
\hline $\mathrm{C}_{\mathrm{f}} / \mathrm{SiC}$ & - & $\mathrm{Nb}$ alloys & Ag-Cu-Ti & $930^{\circ} \mathrm{C}, 15 \mathrm{~min}, 2 \times 10^{-3} \mathrm{~Pa}$ & - & [68] \\
\hline $\mathrm{C}_{\mathrm{f}} / \mathrm{SiC}$ & $3 \mathrm{D}, 1.8 \mathrm{~g} / \mathrm{cm}^{3}, 10-15 \%$ & Ti alloys & $\mathrm{C}_{\mathrm{f}} / \mathrm{Ag}-\mathrm{Cu}-\mathrm{Ti}$ & $900^{\circ} \mathrm{C}, 30 \mathrm{~min}, 2.2 \times 10^{-3} \mathrm{MPa}, 6 \times 10^{-3} \mathrm{~Pa}$ & 84 & [40] \\
\hline
\end{tabular}

TABLE 7: Brazing of $\mathrm{C}_{\mathrm{f}} / \mathrm{SiC}$ composites to metals with high-temperature fillers.

\begin{tabular}{|c|c|c|c|c|c|c|}
\hline CMCs & Basic information & Metal & Brazing material & Process parameters & $\begin{array}{c}\text { Shear } \\
\text { strength }(\mathrm{MPa})\end{array}$ & Ref. \\
\hline $\mathrm{C}_{\mathrm{f}} / \mathrm{SiC}$ & $\begin{array}{c}3 \mathrm{D}, 2.0-2.1 \mathrm{~g} / \mathrm{cm}^{3} \\
10-15 \text { vol. } \%, 400 \mathrm{MPa}\end{array}$ & Ti alloys & Ag-Cu-Ti + 15 vol. $\% \mathrm{~W}$ & $900^{\circ} \mathrm{C}, 5 \mathrm{~min}, 2.2 \times 10^{-3} \mathrm{MPa}, 6 \times 10^{-3} \mathrm{~Pa}$ & 180 & [38] \\
\hline $\mathrm{C}_{\mathrm{f}} / \mathrm{SiC}$ & $\begin{array}{l}3 \mathrm{D}, \mathrm{PIP}, 1.7-1.8 \mathrm{~g} / \mathrm{cm}^{3} \\
10-15 \text { vol. } \%, 400 \mathrm{MPa}\end{array}$ & $\mathrm{TC}_{4}$ alloys & $\begin{array}{c}\mathrm{Ti}-\mathrm{Zr}-\mathrm{Cu}-\mathrm{Ni}+15 \text { vol. } \% \\
\mathrm{~W}\end{array}$ & $930^{\circ} \mathrm{C}, 20 \mathrm{~min}, 6 \times 10^{-3} \mathrm{~Pa}$ & 166 & [46] \\
\hline $\mathrm{C}_{\mathrm{f}} / \mathrm{SiC}$ & $3 \mathrm{D}$ & 42CrMo & Ag-Cu- $\mathrm{Ti}+5$ vol. $\% \mathrm{Mo}$ & $900^{\circ} \mathrm{C}, 10 \mathrm{~min}$, vacuum & $587(\mathrm{BS})$ & {$[78]$} \\
\hline $\mathrm{C}_{\mathrm{f}} / \mathrm{SiC}$ & $3 \mathrm{D}, \mathrm{PIP}$ & $\mathrm{Nb}$ & Ti-Cu-Ni-Zr & $930^{\circ} \mathrm{C}, 10 \mathrm{~min}, 5 \times 10^{-3} \mathrm{~Pa}$ & 124 & [69] \\
\hline $\mathrm{C}_{\mathrm{f}} / \mathrm{SiC}$ & $3 \mathrm{D}$ & Ti-6Al-4V & $\mathrm{Ti}+(\mathrm{Ti}-\mathrm{Cu}-\mathrm{Ni}-\mathrm{Zr})$ & $940^{\circ} \mathrm{C}, 20 \mathrm{~min}, 5 \times 10^{-3} \mathrm{~Pa}$ & 283 & [47] \\
\hline $\mathrm{C}_{\mathrm{f}} / \mathrm{SiC}$ & $\begin{array}{c}3 \mathrm{D}, \text { PIP, } 1.98 \mathrm{~g} / \mathrm{cm}^{3} \\
21.5 \text { vol. } \%\end{array}$ & $\mathrm{Nb}-1 \mathrm{Zr}$ & $\mathrm{Ti}-\mathrm{Co}-\mathrm{Nb}$ & $1280^{\circ} \mathrm{C}, 10 \mathrm{~min}, 1.0-3.0 \times 10^{-3} \mathrm{~Pa}$ & 242 & {$[43]$} \\
\hline $\mathrm{C}_{\mathrm{f}} / \mathrm{SiC}$ & $\begin{array}{c}3 \mathrm{D}, \mathrm{PIP}, 1.86 \mathrm{~g} / \mathrm{cm}^{3} \\
11.7 \text { vol. } \%\end{array}$ & $\mathrm{Ti} \mathrm{Al}$ alloys & $\mathrm{TiH}_{2}-\mathrm{Ni}-\mathrm{B}$ & $1180^{\circ} \mathrm{C}, 10 \mathrm{~min}, 5 \times 10^{-3} \mathrm{~Pa}$ & 105 & [71] \\
\hline
\end{tabular}

reduced and the residual stress of the joint is facilitated. However, there are still some shortcomings for brazing process, such as the interface reaction is intense, to produce brittle compounds, which requires the appropriate adjustment of brazing filler and process parameters. More importantly, avoiding bad excessive interface reaction and accessing to excellent mechanical properties of joints are essential.

3.2. Diffusion Bonding. In mid-1950s, the former Soviet Union scientists proposed a diffusion bonding method which was widely used to join ceramic to metals, including the joint of $\mathrm{C}_{\mathrm{f}} / \mathrm{SiC}$ composites to metals (as shown in Figure $7(\mathrm{~b})) . \mathrm{C}_{\mathrm{f}} / \mathrm{SiC}$ composites and metals are contacted with each other under high temperatures, vacuum or inert atmospheres and pressures, and the plastic formation of connected surfaces is close to each other. After a certain period of soaking time, the intermolecular diffusion and chemical reaction are realized. During the diffusion bonding process, the interface is bonded by plastic deformation, diffusion, and creep mechanism. The joining temperature is high, the CTE and elastic modulus of the composites and 


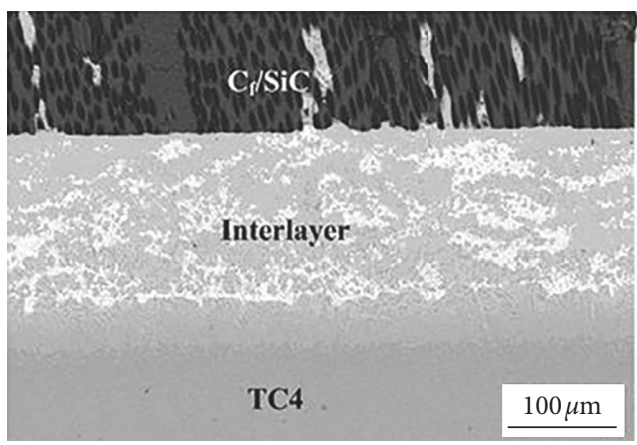

(a)

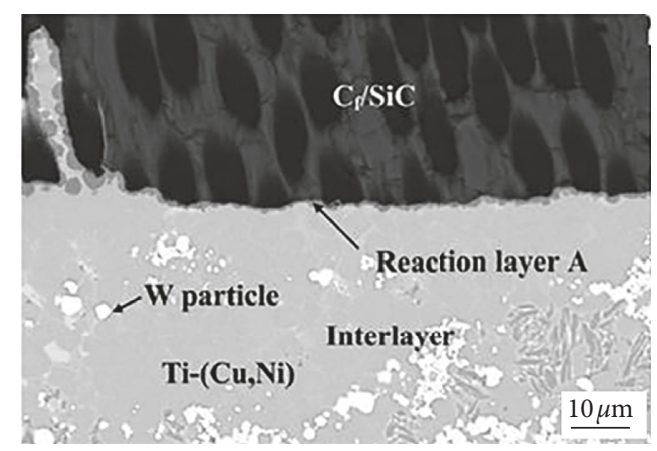

(b)

FIGURE 9: BSE images of the joint: (a) micrograph of the joint; (b) interface between $\mathrm{C}_{\mathrm{f}} / \mathrm{SiC}$ composite and interlayer [46].

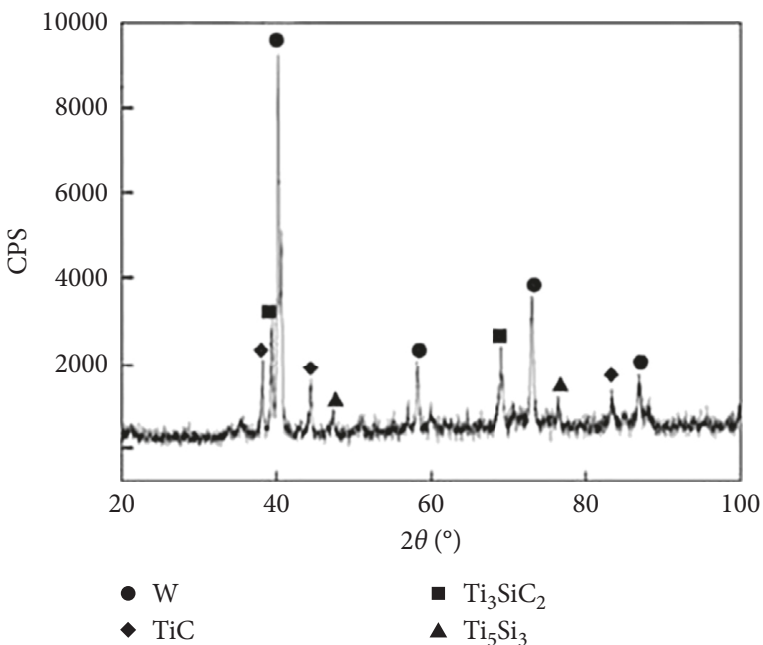

(a)

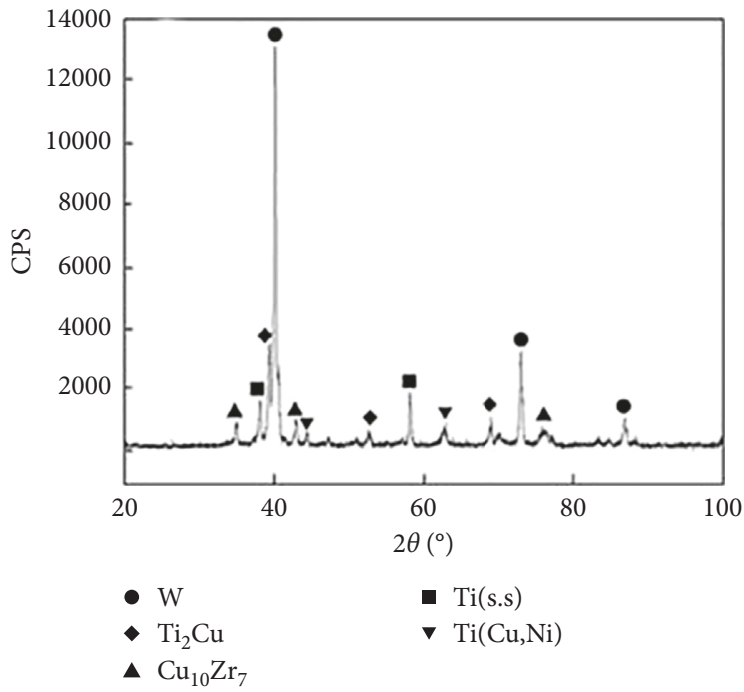

(b)

FIGURE 10: XRD pattern of the joint: (a) interface between $\mathrm{C}_{\mathrm{f}} / \mathrm{SiC}$ composite and interlayer; (b) interlayer [46].

metals are mismatch, and it is easy to induce high residual stress. Due to sharp structural transition near the interface and the lack of a buffer layer to relax the stress, the residual stress is high enough to lead to a lower joint strength.

Simply, diffusion bonding method is a solid-state bonding process, which has been demonstrated as a viable method to overcome the problems encountered in welding. There are many reports on the diffusion bonding $\mathrm{C}_{\mathrm{f}} / \mathrm{SiC}$ composites to metals. In order to join $3 \mathrm{D} / 2 \mathrm{D} \mathrm{C}_{\mathrm{f}} / \mathrm{SiC}$ composite to $\mathrm{Nb}$ alloy, Xiong et al. $[41,42]$ used Ti-Cu foil as the joining material to join $\mathrm{C}_{\mathrm{f}} / \mathrm{SiC}$ composite to $\mathrm{Nb}$ alloy through a two-stage joining process: solid-phase diffusion bonding and transient liquid-phase diffusion bonding. It was found that the Ti-Cu liquid eutectic alloy was formed by the reaction of $\mathrm{Ti}$ and $\mathrm{Cu}$, not only infiltrated into open pores and microcracks as a nail but also reacted with ceramic coating. The remaining $\mathrm{Cu}$ was deformed by own plastic deformation and released the residual stress. In addition, the liquid layer formed by interlayer in the TLP-DB process had good wettability to $\mathrm{C}_{\mathrm{f}} / \mathrm{SiC}$ composite and can infiltrate into
$\mathrm{C}_{\mathrm{f}} / \mathrm{SiC}$ composite matrix and encapsulated $\mathrm{C}_{\mathrm{f}}$ between the interlayer and $\mathrm{C}_{\mathrm{f}} / \mathrm{SiC}$ interface region. These processes were very beneficial for the mechanical strength of the joint. The shear strength of the joint between $2 \mathrm{D} \mathrm{C}_{\mathrm{f}} / \mathrm{SiC}$ composite and $\mathrm{Nb}$ alloy was $14.1 \mathrm{MPa}$, and the shear strength of the joint between $3 \mathrm{D} \mathrm{C} \mathrm{C}_{\mathrm{f}} / \mathrm{SiC}$ composite and $\mathrm{Nb}$ alloy reached up to 34.1 MPa. To our best knowledge, there were mainly two factors leading to a low shear strength of the joint between $2 \mathrm{D} \mathrm{C}_{\mathrm{f}} / \mathrm{SiC}$ composite and $\mathrm{Nb}$ alloy: the CTE mismatch between $2 \mathrm{D} \mathrm{C} \mathrm{C}_{\mathrm{f}} / \mathrm{SiC}$ composite and $\mathrm{Nb}$ alloy was larger compared with $3 \mathrm{D} \mathrm{C}_{\mathrm{f}} / \mathrm{SiC}$ composite and $\mathrm{Nb}$, resulting in a large residual stress, and the fiber direction among $2 \mathrm{D}$ $\mathrm{C}_{\mathrm{f}} / \mathrm{SiC}$ composite was parallel to the joining interface, whereas the fiber direction among $3 \mathrm{D} \mathrm{C} / \mathrm{SiC}$ composite was perpendicular to the joining interface. When the fiber was perpendicular to the joining interface, "nail effect" formed between reaction layer and $C_{f}$ and shared more load than other regions in fracture test (as is shown in Figure 11). These results demonstrated that the direction of fiber was directly related to the interface structure of the joint, which 


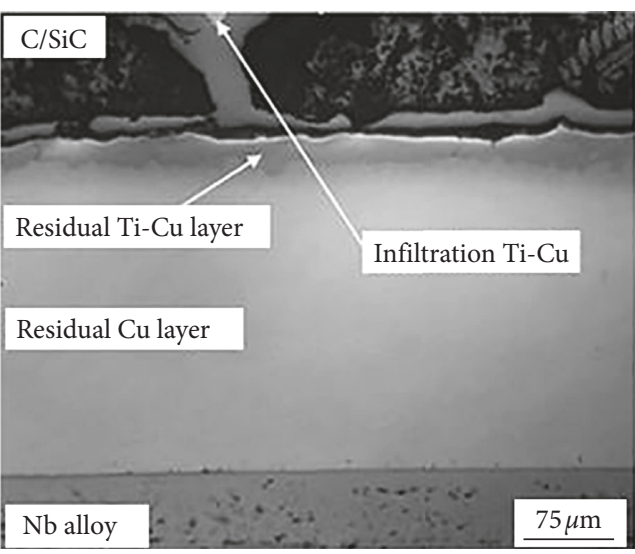

(a)

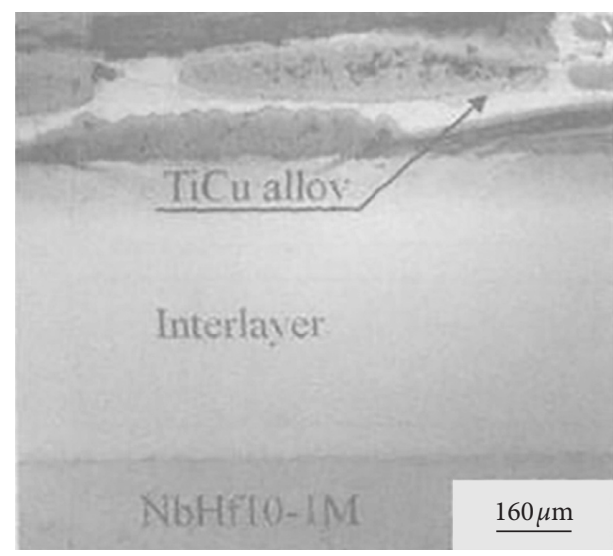

(b)

Figure 11: SEM micrograph of the joint: (a) 3D $\mathrm{C}_{\mathrm{f}} / \mathrm{SiC}$ and (b) $2 \mathrm{D} \mathrm{C}_{\mathrm{f}} / \mathrm{SiC}[41,42]$.

in turn affected the shear strength of joint. In this kind of research work, the influence of fiber must be considered; however, this interesting topic has not yet been studied systematically.

In addition, the reactions between joining material and composite matrix have been recently recognized as critical factors for determining the strength of the joint. $\mathrm{C}_{\mathrm{f}} / \mathrm{SiC}$ composite and Ti-6Al-4V alloy were joined by Ban et al. [79] with the mixed powder of $\mathrm{Cu}, \mathrm{Ti}$, and graphite under vacuum environment. In situ synthetic $\mathrm{TiC}$ that reduced the thermal stress significantly was synthesized by interdiffusing of $\mathrm{C}$ element in the graphite particle and Ti element in the liquid bonding layer (as is shown in Figure 12). The positive effect of TiC on joint strength was also described in other papers $[56,72,80]$. Table 8 summarizes the data of diffusion bonded joining. The utility model has the advantages of high strength, stable joint quality, and good corrosion resistance, especially for the joining of $\mathrm{C}_{\mathrm{f}} / \mathrm{SiC}$ composites and metals for high-temperature and corrosion-resistance application.

3.3. Online Liquid Infiltration Joining. Online liquid infiltration joining is a novel technology, which is applied to the joining of fiber-reinforced ceramic matrix composites. $\mathrm{C}_{\mathrm{f}} / \mathrm{SiC}$ composites are usually porous both for CVI and PIP processing. An online liquid infiltration joining method that is suitable for the composites was reported. The porosity of $\mathrm{C}_{\mathrm{f}} / \mathrm{SiC}$ composites was controlled and then the compact process was carried out after the joining has finished, which reduced the damnification of joints as much as possible. The wettability between the joining material and $\mathrm{C}_{\mathrm{f}} / \mathrm{SiC}$ composite was improved; moreover, the joining material could be melted and infiltrated into the $\mathrm{C}_{\mathrm{f}} / \mathrm{SiC}$ matrix, which increased the joining area and reinforced the joint strength $[81,82]$. In addition, a root-like morphology was formed in $\mathrm{C}_{\mathrm{f}} / \mathrm{SiC}$ composite substrate, which could greatly enhance the reliability of joint [83].

The only paper that attempts to join $\mathrm{C}_{\mathrm{f}} / \mathrm{SiC}$ composite to metal via online liquid infiltration joining was presented in 2004 [84]. The authors joined $2 \mathrm{D} / 3 \mathrm{D} \mathrm{C} / \mathrm{SiC}$ composites to $\mathrm{Nb}$ with Ni-based filler by the online liquid infiltration joining method (as shown in Figure 13). The joint between $2 \mathrm{D} \mathrm{C}_{\mathrm{f}} / \mathrm{SiC}$ composite and $\mathrm{Nb}$ was failure and separated during the cooling. However, the favorable joint between 3D $\mathrm{C}_{\mathrm{f}} / \mathrm{SiC}$ composite and $\mathrm{Nb}$ was obtained. Approaches such as reactive brazed $[68,69]$ and diffusion bonding $[41,42]$ have also been successfully used to join $\mathrm{C}_{\mathrm{f}} / \mathrm{SiC}$ composites to $\mathrm{Nb}$ alloy. Unfortunately, the bonding processes above were usually conducted after the preparation of the composite matrix, which damaged the strength of the matrix. Online liquid infiltration joining, which is completed in the preparation process, is different from the above methods. Afterward, chemical vapor deposition (CVD) process not only complete the preparation of materials but also can provide antioxidation coating for the matrix and the joint, reflects the joining, preparation, and processing integration $[51,85]$.

3.4. Ultrasonic-Assisted Joining. Ultrasonic-assisted joining is employed to join aluminum alloy structural parts at first. Afterward, ultrasonic is used for copper and alloy, gradually widely used in CMCs and metals, as shown in Figure 14 [86]. Since ultrasound exists as an energy form, it produces some unique ultrasonic effects when it propagates in the medium. The ultrasonic-assisted joining utilizes ultrasonic vibrations to interact the contact area of the CMCs with the metal. The ultrasonic effect causes the liquid joining material to spread on the surface of the matrix and form a joint with the metal [87]. In 1990s, ultrasonicassisted joining technology facilitated the wetting of materials with poor wetting properties such as ceramics, glass, and stainless steel [88-90,94]. The liquid-connecting materials spread and moisten, through the ultrasonic wave effect that from the vibrations of ultrasonic, the surface of the CMCs and metal to achieve good connection. Moreover, it is worth mentioning that ultrasonic-assisted joining technology can improve the wettability of connection materials on the surface of matrixes such as ceramics, glass, and stainless steel. Therefore, this technology has been widely applied in many fields.

The joining of $\mathrm{SiC}$ and $\mathrm{Ti}-6 \mathrm{Al}-4 \mathrm{~V}$ alloy via ultrasonicassisted joining was conducted by Chen et al. [91, 92]. SiC 

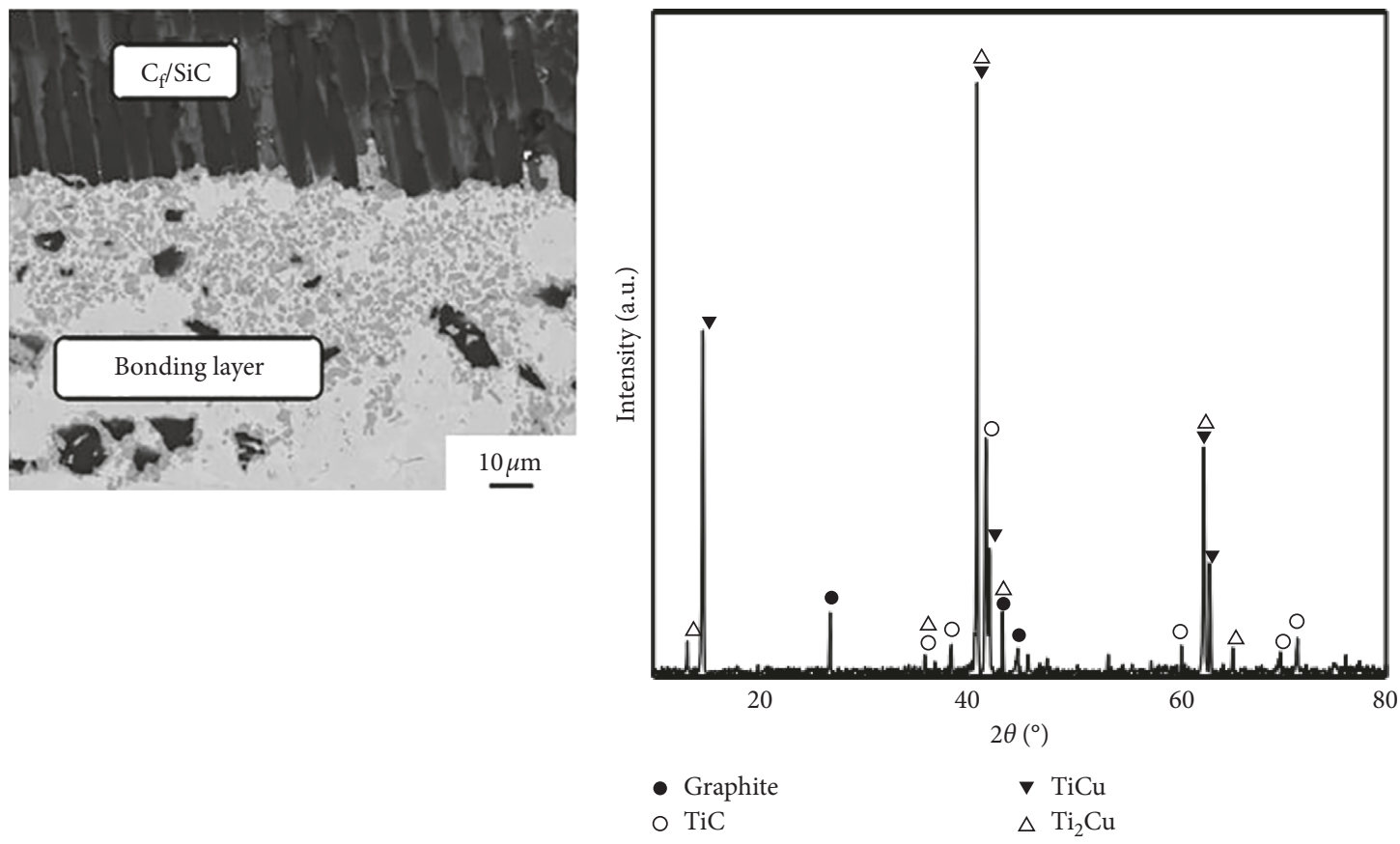

(a)

(b)

Figure 12: (a) Micrographs and (b) XRD pattern of the interface [79].

Table 8: Diffusion bonding of $\mathrm{C}_{\mathrm{f}} / \mathrm{SiC}$ composites to metals.

\begin{tabular}{|c|c|c|c|c|c|c|}
\hline CMCs & Basic information & Metal & Joining material & Process parameter & $\begin{array}{c}\text { Shear } \\
\text { strength }(\mathrm{MPa})\end{array}$ & Ref. \\
\hline $\mathrm{C}_{\mathrm{f}} / \mathrm{SiC}$ & $3 \mathrm{D}, \mathrm{CVI}, 2.1 \mathrm{~g} / \mathrm{cm}^{3}$ & $\mathrm{Nb}$ alloy & Ti-Cu bi-foil & $\begin{array}{c}800^{\circ} \mathrm{C}, 30 \mathrm{~min}, 6 \mathrm{MPa} ; 1020^{\circ} \mathrm{C}, 60 \mathrm{~min}, \\
0.05 \mathrm{MPa}, 3.2 \times 10^{-3} \mathrm{~Pa}\end{array}$ & 34.1 & [41] \\
\hline $\mathrm{C}_{\mathrm{f}} / \mathrm{SiC}$ & 2D, CVI, 16 vol.\% & $\mathrm{Nb}$ alloy & $\mathrm{Ti}-\mathrm{Cu}-\mathrm{Cu}$ & $\begin{array}{c}850^{\circ} \mathrm{C}, 40 \mathrm{~min}, 8 \mathrm{MPa} ; 980^{\circ} \mathrm{C}, 30 \mathrm{~min}, \\
0.05 \mathrm{MPa}, 3.2 \times 10^{-3} \mathrm{~Pa}\end{array}$ & 14.1 & {$[42]$} \\
\hline $\mathrm{C}_{\mathrm{f}} / \mathrm{SiC}$ & $\begin{array}{c}3 \mathrm{D}, 2.0-2.1 \mathrm{~g} / \mathrm{cm}^{3} \\
10-15 \text { vol. } \%, 400 \mathrm{MPa}\end{array}$ & $\mathrm{TC}_{4}$ alloy & $\mathrm{Cu}-\mathrm{Ti}-\mathrm{C}$ & $900-950^{\circ} \mathrm{C}, 5-30 \mathrm{~min}, 6.0 \times 10^{-3} \mathrm{~Pa}$ & - & [79] \\
\hline $\mathrm{C}_{\mathrm{f}} / \mathrm{SiC}$ & $3 \mathrm{D}, 15$ vol. $\%, 500 \mathrm{MPa}$ & $\mathrm{Ni}$ alloy & $\mathrm{Zr} / \mathrm{Ta}$ & $1050^{\circ} \mathrm{C}, 10 \mathrm{~min}, 40.8 \mathrm{MPa}, 10^{-2} \mathrm{~Pa}$ & 110.89 (BS) & [70] \\
\hline
\end{tabular}

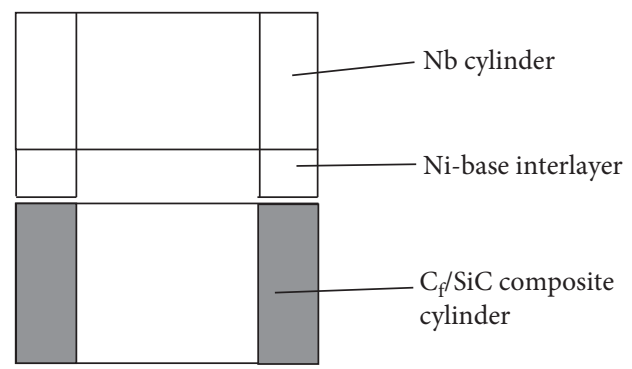

FIGURE 13: The diagram of specimens before being joined.

was employed by a joining material with an $\mathrm{Al}-12 \mathrm{Si}$ alloy at low temperature $\left(620^{\circ} \mathrm{C}\right)$, and the shear strength of the joint was $84-94 \mathrm{MPa}$. In their study, the oxide layer of the matrix was broken by the ultrasonic, and the joining material can form a good interface between $\mathrm{SiC}$ and Ti-6Al-4V alloy. However, cracks were observed in $\mathrm{SiC}$ material and the

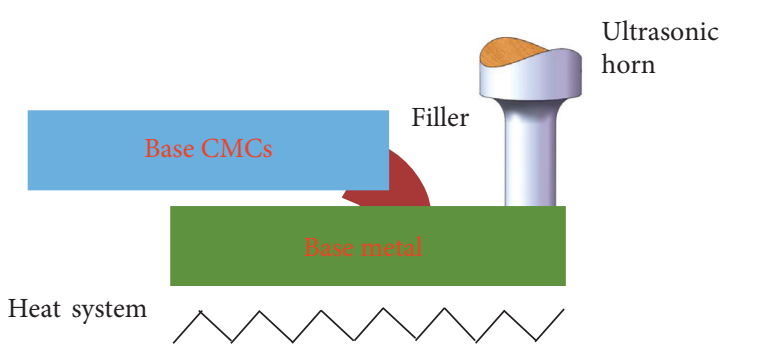

FIgURE 14: The diagram of capillary process that filler gets into clearance by action of ultrasonic vibration.

propagation direction was parallel to joint. The main reason was that the nonuniform shrinkage of material at the joint and residual stress, which leads to crack formation in the SiC substrate, was produced during the cooling process. They obtained an integrated joint when using the novel joining 
material in their study. $\mathrm{SiC}$ and $\mathrm{Ti}-6 \mathrm{Al}-4 \mathrm{~V}$ alloy were joined with AlSnSiZnMg mixed metal, which reduced the joining temperature and the residual stress of the joint, inhibiting the occurrence of cracks and other defects. Unfortunately, the shear strength of the joint was not improved (77.8 MPa).

On the other hand, ultrasonic-assisted joining technology can also be used to join oxide ceramics to metals. Naka et al. [88] joined $\mathrm{Al}_{2} \mathrm{O}_{3}$ to $\mathrm{Cu}$ with $\mathrm{Zn}, \mathrm{Zn}-5 \mathrm{Al}$, and $\mathrm{Zn}_{100-x}\left(\mathrm{Al}_{0.6}+\mathrm{Cu}_{0.4}\right)_{x}(x=0-30)$ as the joining materials. It was shown that with the time and joining temperature increased, the shear strength of the joint with $\mathrm{Zn}-6 \mathrm{Al}-4 \mathrm{Cu}$ filler was improved and reached $\sim 62 \mathrm{MPa}$. In the above literatures, some of them were reported that the ultrasound was beneficial to improve the wettability of $\mathrm{Al}_{2} \mathrm{O}_{3}$ and metals.

The mechanism of ultrasonic effect on the joining process can be summarized as follows: (1) the macroscopic bubbles between the filled metal and the ceramic were removed by the ultrasonic cavitation; (2) the $\mathrm{C}_{\mathrm{f}} / \mathrm{SiC}$ substrate surface was subjected to high-speed impact of atoms under ultrasonic vibration; (3) the ultrasonic vibration and friction between the joining material and metal.

3.5. Electric-Assisted Field Joining. Although diffusion bonding is widely used to join CMCs and metals, generally, it requires high temperatures, high pressure, vacuum or inert atmosphere, and long joining time [93, 94, 98]. Electricassisted field joining is an effective way to solve these above problems, as shown in Figure 15. Since the joining between CMCs and metal was realized by chemical reaction, interfacial structure formed by reaction determines the mechanical properties of the joint. Better joint can be obtained using the electric-assisted field method.

The interface between CMCs and metal were polarized under electrostatic field. On the one hand, it promotes atomic migration and vacancy diffusion. On the other hand, it accelerates the interface reaction, which reduces the joining temperature, the pressure, and the residual stress. Moreover, the interface reaction is easy to control, and joining time is very short $[96-98,101]$.

Initially, the electric-assisted field joining is mainly employed for joining ceramics to metals [100]. The interface composition and mechanical properties of joints between $\mathrm{SiC}$ and $\mathrm{Ti}$ were investigated by Wang et al. [98] in the electric field. It was shown that the external electric field reduced the joining temperature and time and improved the shear strength. It is important that the external electric field can improve the diffusion rate of interface atoms. Moreover, it promoted the interface reaction and improved the joining efficiency.

Owing to its simplicity and efficiency, electric-assisted field joining became a useful method employed for joining $\mathrm{C}_{\mathrm{f}} / \mathrm{C}$ composites [101] and $\mathrm{C}_{\mathrm{f}} / \mathrm{SiC}$ composites [48]. $\mathrm{C}_{\mathrm{f}} / \mathrm{C}$ composites were firstly joined by combining electric fieldassisted sintering technology and using a $\mathrm{Ti}_{3} \mathrm{SiC}_{2}$ tape film as the interlayer [101]. In their work, the interdiffusion speed between the interlayer and the metal was accelerated by an electric field and the joining time was only $12 \mathrm{~min}$. To our

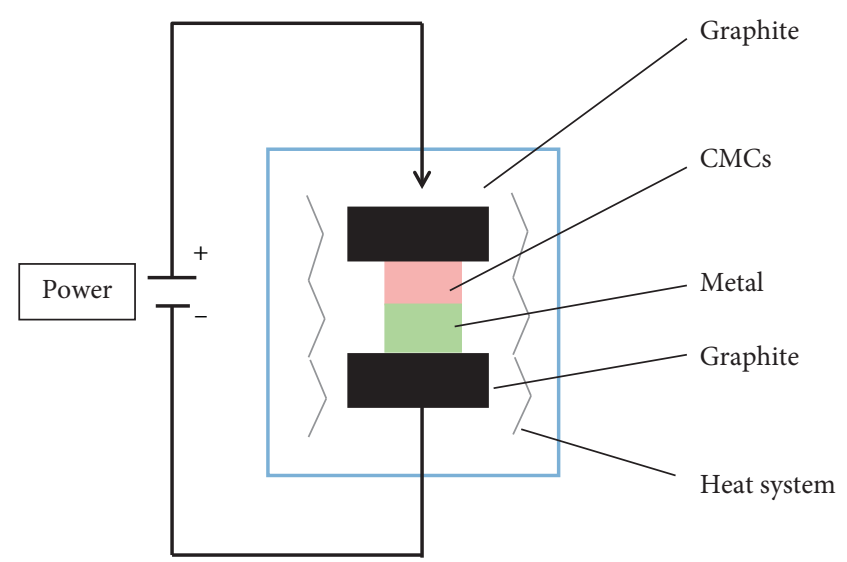

FIgURE 15: The diagram of the experimental equipment under electric field.

knowledge, the $\mathrm{Ti}_{3} \mathrm{SiC}_{2}$ exhibited pseudoplastic at $1300^{\circ} \mathrm{C}$ or higher $[102,103]$. Therefore, $\mathrm{Ti}_{3} \mathrm{SiC}_{2}$ infiltrated into the composite matrix and a "nail" that clamps the matrix was observed, as shown in Figure 16, which improved shear strength of the joint. In the joining process, two key factors affected the strength of the joint: (1) the interdiffusion between the joining material and the matrix was promoted by electric field and (2) $\mathrm{Ti}_{3} \mathrm{SiC}_{2}$ showed good plastic deformation ability in the electric field.

Atoms spread to the interface under electric field. It is necessary to pass through the potential through the gap, the original position occupied by their own formed a new space. The energy of the atoms across the barrier was provided by the electric field. At the same time, the atoms across the barrier potential energy are reduced by the electric field. Combined with these two effects, the diffusion activation of atoms can be greatly reduced, thereby increasing the diffusion rate of solute atoms and obtaining a uniform structure [104]. Therefore, the electric-assisted fields joining method has drawn great attention and is expected to become an important way for the joining of $\mathrm{C}_{\mathrm{f}} / \mathrm{SiC}$ composites in the future.

\section{Summary}

With the rapid development of high-tech in aerospace and other industry fields, carbon fiber-reinforced silicon carbide $\left(\mathrm{C}_{\mathrm{f}} / \mathrm{SiC}\right)$ ceramic matrix composites, one of the most famous $\mathrm{CMCs}$, are becoming the most promising candidates for high-temperature structural applications. In most cases, typically, it is very difficult to produce large-size $\mathrm{C}_{\mathrm{f}} / \mathrm{SiC}$ composite components with complex shapes, resulting in that they must be joined with themselves or other materials by appropriate joining technologies. At present, various joining technologies of $\mathrm{C}_{\mathrm{f}} / \mathrm{SiC}$ composites are reported, including the joining of $\mathrm{C}_{\mathrm{f}} / \mathrm{SiC}-\mathrm{C}_{\mathrm{f}} / \mathrm{SiC}$ and $\mathrm{C}_{\mathrm{f}} / \mathrm{SiC}$-metal, such as direct bonding of $\mathrm{C}_{\mathrm{f}} / \mathrm{SiC}-\mathrm{C}_{\mathrm{f}} / \mathrm{SiC}$, indirect bonding of $\mathrm{C}_{\mathrm{f}} / \mathrm{SiC}-\mathrm{C}_{\mathrm{f}} / \mathrm{SiC}$, brazing of $\mathrm{C}_{\mathrm{f}} / \mathrm{SiC}$-metal, diffusion bonding of $\mathrm{C}_{\mathrm{f}} / \mathrm{SiC}$-metal, online liquid infiltration of $\mathrm{C}_{\mathrm{f}} / \mathrm{SiC}$-metal, ultrasonic-assisted joining of $\mathrm{C}_{\mathrm{f}} / \mathrm{SiC}$-metal, and electricassisted joining of $\mathrm{C}_{\mathrm{f}} / \mathrm{SiC}$-metal. 


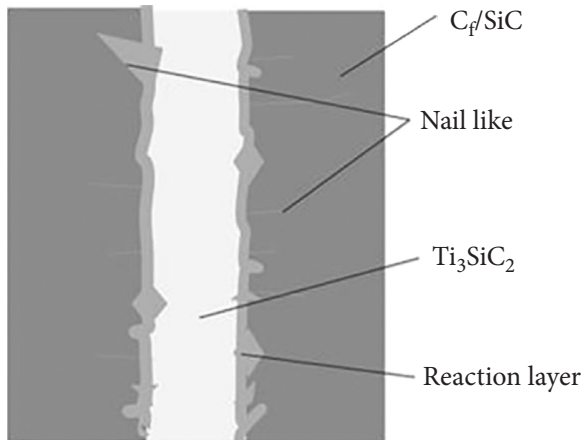

(a)

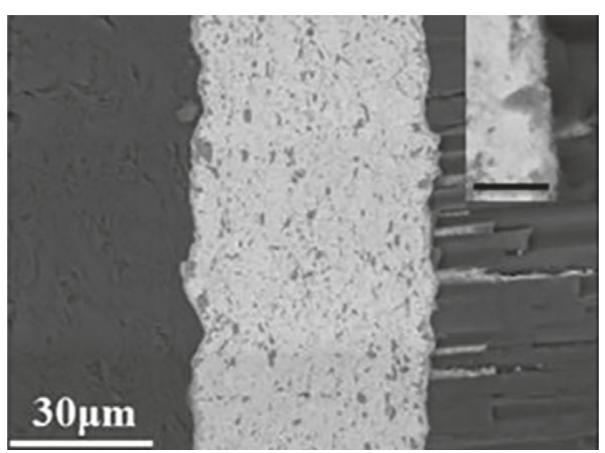

(b)

FIgURE 16: (a) The schematic diagram of "nail" like and (b) BSE image [101].

To the best knowledge of the authors, however, there has been no systematic summary of the joining of $\mathrm{C}_{\mathrm{f}} \mathrm{SiC}$ composites. In this paper, a systematic review of the joining of $\mathrm{C}_{\mathrm{f}} / \mathrm{SiC}$ composites is conducted, and the aim of this paper is to provide some reference for researchers working on this field.

\section{Conflicts of Interest}

The authors declare that they have no conflicts of interest.

\section{Acknowledgments}

The authors sincerely thank the Young Elite Scientist Sponsorship (YESS) Program by CAST (No. 2015QNRC001) and the Beijing Institute of Technology Research Fund Program for Young Scholars.

\section{References}

[1] A. Luna Ramírez, J. Porcayo-Calderon, Z. Mazur et al., "Microstructural changes during high temperature service of a cobalt-based superalloy first stage nozzle," Advances in Materials Science and Engineering, vol. 2016, pp. 1-7, 2016.

[2] A. Baldan, "Progress in Ostwald ripening theories and their applications to nickel-base superalloys. Part I: Ostwald ripening theories," Journal of Materials Science, vol. 37, no. 11, pp. 2171-2202, 2002.

[3] M. V. Acharya and G. E. Fuchs, "The effect of long-term thermal exposures on the microstructure and properties of CMSX-10 single crystal Ni-base superalloys," Materials Science and Engineering: A, vol. 381, no. 1-2, pp. 143-153, 2004.

[4] B. S. Sung and Y. H. Yun, "SiC conversion coating prepared from silica-graphite reaction," Advances in Materials Science and Engineering, vol. 2017, no. 5, pp. 1-8, 2017.

[5] N. S. Jacobson, K. N. Lee, and D. S. Fox, "Reactions of silicon carbide and silicon(IV) oxide at elevated temperatures," Journal of the American Ceramic Society, vol. 75, no. 6, pp. 1603-1611, 1992.

[6] S. V. Ushakov and A. Navrotsky, "Experimental approaches to the thermodynamics of ceramics above $1500^{\circ} \mathrm{C}$," Journal of the American Ceramic Society, vol. 95, no. 5, pp. 1463-1482, 2012.

[7] J. Llorca and R. N. Singh, "Influence of fiber and interfacial properties on fracture behavior of fiber-reinforced ceramic composites," Journal of the American Ceramic Society, vol. 74, no. 11, pp. 2882-2890, 1991.

[8] Q. Xie and S. N. Wosu, "Dynamic fracture toughness of TaC/ CNTs/SiC CMCs prepared by spark plasma sintering," Advances in Materials Science and Engineering, vol. 2015, no. 2, pp. 1-8, 2015.

[9] C. J. Liu, W. F. Ding, T. Y. Yu, and C. Y. Yang, "Materials removal mechanism in high-speed grinding of particulate reinforced titanium matrix composites," Precision Engineering, vol. 51, pp. 68-77, 2018.

[10] X. Ma, S. A. Chen, M. Mei et al., "Microstructure and mechanical behaviors of T700 carbon fiber reinforced $\mathrm{C} / \mathrm{SiC}$ composites via precursor infiltration and pyrolysis," Materials Science and Engineering: A, vol. 666, pp. 238-244, 2016.

[11] S. Schmidt, S. Beyer, H. Knabe et al., "Advanced ceramic matrix composite materials for current and future propulsion technology applications," Acta Astronautica, vol. 55, no. 3, pp. 409-420, 2004.

[12] L. Wang, F. Hou, X. Wang, J. C. Liu, and A. Guo, "Preparation and mechanical properties of continuous carbon nanotube networks modified $\mathrm{C}_{\mathrm{f}} / \mathrm{SiC}$ composite," Advances in Materials Science and Engineering, vol. 2015, no. 12, pp. 1-7, 2015.

[13] M. Z. Berbon, D. R. Dietrich, and D. B. Marshall, "Transverse thermal conductivity of thin $\mathrm{C} / \mathrm{SiC}$ composites fabricated by slurry infiltration and pyrolysis," Journal of the American Ceramic Society, vol. 84, no. 10, pp. 2229-2234, 2001.

[14] W. Yang, L. Zhang, L. Cheng et al., "Oxidation behavior of $\mathrm{C}_{\mathrm{f}} / \mathrm{SiC}$ composite with CVD SiC- $\mathrm{B}_{4} \mathrm{C}$ coating in a wet oxygen environment," Applied Composite Materials, vol. 16, no. 2, pp. 83-92, 2009.

[15] G. Boitier, J. L. Chermant, and J. Vicens, "Bridging at the nanometric scale in $2.5 \mathrm{D} \mathrm{C} \mathrm{C}_{\mathrm{f}}$-SiC composites," Applied Composite Materials, vol. 6, no. 5, pp. 279-287, 1999.

[16] P. Tatarko, Z. Chlup, A. Mahajan et al., "High temperature properties of the monolithic CVD-SiC materials joined with a pre-sintered MAX phase $\mathrm{Ti}_{3} \mathrm{SiC}_{2}$ interlayer via solid-state diffusion bonding," Journal of the European Ceramic Society, vol. 37, no. 4, pp. 1205-1216, 2017.

[17] G. B. Zheng, H. Sano, Y. Uchiyama, K. Kobayashi, and H. M. Cheng, "The properties of carbon fibre/SiC composites fabricated through impregnation and pyrolysis of polycarbosilane," Journal of Materials Science, vol. 34, no. 4, pp. 827-834, 1999.

[18] K. Jian, Z. H. Chen, Q. S. Ma, and W. W. Zheng, "Effects of pyrolysis processes on the microstructures and mechanical properties of $\mathrm{C}_{\mathrm{f}} / \mathrm{SiC}$ composites using polycarbosilane," 
Materials Science and Engineering: A, vol. 390, no. 1, pp. 154-158, 2005.

[19] K. Jian, Z. H. Chen, Q. S. Ma, H. F. Hu, and W. W. Zheng, "Processing and properties of $2 \mathrm{D}-\mathrm{C}_{\mathrm{f}} / \mathrm{SiC}$ composites incorporating SiC fillers," Materials Science and Engineering: A, vol. 408, no. 1, pp. 330-335, 2005.

[20] C. C. Zhou, C. R. Zhang, H. F. Hu et al., "Preparation of 3D$\mathrm{C}_{\mathrm{f}} / \mathrm{SiC}$ composites at low temperatures," Materials Science and Engineering: A, vol. 488, no. 1, pp. 569-572, 2008.

[21] M. Broda, A. Pyzalla, and W. Reimers, "X-ray analysis of residual stresses in $\mathrm{C} / \mathrm{SiC}$ composites," Applied Composite Materials, vol. 6, no. 1, pp. 51-66, 1999.

[22] J.-C. Bae, K.-Y. Cho, D.-H. Yoon et al., "Highly efficient densification of carbon fiber-reinforced SiC-matrix composites by melting infiltration and pyrolysis using polycarbosilane," Ceramics International, vol. 39, no. 5, pp. 5623-5629, 2013.

[23] Z. S. Rak, "A process for $\mathrm{C}_{\mathrm{f}} / \mathrm{SiC}$ composites using liquid polymer infiltration," Journal of the American Ceramic Society, vol. 84, no. 10, pp. 2235-2239, 2001.

[24] L. B. Li, "Comparison of fatigue life between $\mathrm{C} / \mathrm{SiC}$ and $\mathrm{SiC} /$ $\mathrm{SiC}$ ceramic-matrix composites at room and elevated temperatures," Applied Composite Materials, vol. 23, no. 5, pp. 913-952, 2016.

[25] G. V. Samsonov and B. A. Kovenskaya, "The nature of the chemical bond in borides," in Boron and Refractory Borides, pp. 19-30, Springer-Verlag, Berlin, Germany, 1977.

[26] S. Suyama, T. Kameda, and Y. Itoh, "Development of highstrength reaction-sintered silicon carbide," Diamond and Related Materials, vol. 12, no. 3, pp. 1201-1204, 2003.

[27] Y. Z. Zhu, Z. R. Huang, and S. M. Dong, "Manufacturing 2D carbon-fiber-reinforced $\mathrm{SiC}$ matrix composites by slurry infiltration and PIP process," Ceramics International, vol. 34, no. 5, pp. 1201-1205, 2008.

[28] Q. Zhou, S. M. Dong, X. Y. Zhang, and D. Jiang, "Fabrication of $\mathrm{C}_{\mathrm{f}} / \mathrm{SiC}$ composites by vapor silicon infiltration," Journal of the American Ceramic Society, vol. 89, no. 7, pp. 2338-2340, 2006.

[29] M. N. Saleh, Y. Wang, A. Yudhanto et al., "Investigating the potential of using off-axis 3D woven composites in composite joints' applications," Applied Composite Materials, vol. 24, no. 2, pp. 377-396, 2017.

[30] D. Y. Fan, J. H. Huang, X. P. Zhao et al., "Joining of $\mathrm{C}_{\mathrm{f}} / \mathrm{SiC}$ composite to Ti-6Al-4V with (Ti-Zr-Cu-Ni)+Ti filler based on in-situ alloying concept," Ceramics International, vol. 43, no. 5, pp. 4151-4158, 2017.

[31] Y. Katoh, L. L. Snead, T. Cheng et al., "Radiation-tolerant joining technologies for silicon carbide ceramics and composites," Journal of Nuclear Materials, vol. 448, no. 1, pp. 497-511, 2014.

[32] G. D. Li, Y. D. Zhang, C. R. Zhang et al., "Design, preparation and properties of online-joints of $\mathrm{C} / \mathrm{SiC}-\mathrm{C} / \mathrm{SiC}$ with pins," Composites Part B: Engineering, vol. 48, pp. 134-139, 2013.

[33] Z. B. He, L. T. Zhang, Y. Zhang et al., "Microstructural characterization and failure analysis of $2 \mathrm{D} \mathrm{C/SiC}$ two-layer beam with pin-bonded hybrid joints," International Journal of Adhesion and Adhesives, vol. 57, pp. 70-78, 2015.

[34] J. A. Fernie, Joining Ceramic Materials, American Ceramic Society, Westerville, OH, USA, 1997.

[35] X. Y. Wang, Y. Li, S. Z. Wei, and X. D. Ma, "Research progress in connecting techniques of ceramics and metals," Casting Forging Welding, vol. 38, no. 13, pp. 144-148, 2009.

[36] P. Tatarko, V. Casalegno, C. F. Hu et al., "Joining of CVD-SiC coated and uncoated fibre reinforced ceramic matrix composites with pre-sintered $\mathrm{Ti}_{3} \mathrm{SiC}_{2}$ MAX phase using spark plasma sintering," Journal of the European Ceramic Society, vol. 36, no. 16, pp. 3957-3967, 2016.

[37] R. H. Jones, L. Giancarli, A. Hasegawa et al., "Promise and challenges of $\mathrm{SiC}_{\mathrm{f}} / \mathrm{SiC}$ composites for fusion energy applications," Journal of Nuclear Materials, vol. 307, pp. 10571072, 2002.

[38] G. B. Lin, J. H. Huang, H. Zhang, and H. Y. Liu, "Microstructure and mechanical performance of brazed joints of Cf/ $\mathrm{SiC}$ composite and Tialloy using Ag-Cu-Ti-W," Science and Technology of Welding and Joining, vol. 11, no. 4, pp. 379383, 2006.

[39] J. K. Li, L. Liu, Y. T. Wu et al., "Microstructure of high temperature Ti-based brazing alloys and wettability on $\mathrm{SiC}$ ceramic," Materials and Design, vol. 30, no. 2, pp. 275-279, 2009.

[40] G. B. Lin, J. H. Huang, and H. Zhang, "Joints of carbon fiberreinforced $\mathrm{SiC}$ composites to Ti-alloy brazed by $\mathrm{Ag}-\mathrm{Cu}-\mathrm{Ti}$ short carbon fibers," Journal of Materials Processing Technology, vol. 189, no. 1, pp. 256-261, 2007.

[41] J. T. Xiong, J. L. Li, F. S. Zhang, and W. Huang, "Joining of 3D C/SiC composites to niobium alloy," Scripta Materialia, vol. 55, no. 2, pp. 151-154, 2006.

[42] J. T. Xiong, J. L. Li, F. S. Zhang et al., "Joining of 2D C/SiC composites with niobium alloy," Journal of Inorganic Materials, vol. 21, no. 6, pp. 1391-1396, 2006.

[43] Q. Zhang, L. B. Sun, Q. Y. Liu, G. Wang, and Y. Xuan, "Effect of brazing parameters on microstructure and mechanical properties of $\mathrm{Cf} / \mathrm{SiC}$ and $\mathrm{Nb}-1 \mathrm{Zr}$ joints brazed with $\mathrm{Ti}-\mathrm{Co}-$ $\mathrm{Nb}$ filler alloy," Journal of the European Ceramic Society, vol. 37, no. 3, pp. 931-937, 2017.

[44] S. J. Li, Y. Zhou, and H. P. Duan, "Joining of SiC ceramic to Ni-based superalloy with functionally gradient material fillers and a tungsten intermediate layer," Journal of Materials Science, vol. 38, no. 19, pp. 4065-4070, 2003.

[45] C. Jiménez, C. Wilhelmi, and T. Speliotis, "Joining of C/SiC Ceramics to Nimonic Alloys," Journal of Materials Engineering and Performance, vol. 21, no. 5, pp. 683-689, 2012.

[46] B. Cui, J. H. Huang, C. Cai, S. Chen, and X. Zhao, "Microstructures and mechanical properties of $\mathrm{C}_{\mathrm{f}} / \mathrm{SiC}$ composite and $\mathrm{TC}_{4}$ alloy joints brazed with (Ti-Zr-Cu-Ni)+W composite filler materials," Composites Science and Technology, vol. 97, pp. 19-26, 2014.

[47] Y. Liu, Z. R. Huang, and X. J. Liu, "Joining of sintered silicon carbide using ternary Ag-Cu-Ti active brazing alloy," $\mathrm{Ce}$ ramics International, vol. 35, no. 8, pp. 3479-3484, 2009.

[48] S. Rizzo, S. Grasso, M. Salvo et al., "Joining of C/SiC composites by spark plasma sintering technique," Journal of the European Ceramic Society, vol. 34, no. 4, pp. 903-913, 2014.

[49] B. Chen, H. P. Xiong, Y. Y. Cheng et al., "Microstructure and strength of $\mathrm{Cf} / \mathrm{SiC}$ joints with $\mathrm{Ag}$-Cu-Ti brazing fillers," Journal Materials Engineering, vol. 329, pp. 27-31, 2010.

[50] D. Y. Fan, J. H. Huang, X. W. Sun et al., "Correlation between microstructure and mechanical properties of active brazed $\mathrm{C}_{\mathrm{f}} / \mathrm{SiC}$ composite joints using Ti-Zr-Be," Materials Science Engineering: A, vol. 667, pp. 332-339, 2016.

[51] Q. Y. Tong, L. F. Cheng, and L. T. Zhang, "Microstructure and properties of joints of $2 \mathrm{D} \mathrm{C} / \mathrm{SiC}$ composites," Materials Engineering, vol. 11, pp. 14-16, 2002.

[52] Q. Y. Tong, L. F. Cheng, and L. T. Zhang, "On-line joining of 3D fiber reinforced C/SiC composites," Rare Metal Materials and Engineering, vol. 33, no. 1, pp. 101-104, 2004. 
[53] Q. Y. Tong and L. F. Cheng, "Liquid infiltration joining of 2D C/SiC composite," Science Engineering Composites Materials, vol. 13, no. 1, pp. 31-36, 2006.

[54] Y. Katoh, M. Kotani, A. Kohyama et al., "Microstructure and mechanical properties of low-activation glass-ceramic joining and coating for SiC/SiC composites," Journal of Nuclear Materials, vol. 283, pp. 1262-1266, 2000.

[55] H. Y. Dong, S. J. Li, Y. Y. Teng, and W. Ma, "Joining of SiC ceramic-based materials with ternary carbide $\mathrm{Ti}_{3} \mathrm{SiC}_{2}$," Materials Science and Engineering: B, vol. 176, no. 1, pp. 60-64, 2011.

[56] X. B. Zhou, Y. H. Han, X. F. Shen et al., "Fast joining SiC ceramics with $\mathrm{Ti}_{3} \mathrm{SiC}_{2}$ tape film by electric field-assisted sintering Technol," Journal of Nuclear Materials, vol. 466, pp. 322-327, 2015.

[57] J. Suo, Z. H. Chen, W. M. Han, and W. Zheng, "Joining of ceramic materials by ceramic bonding transformed from silicone resin at high temperature," Journal of The Chinese Ceramic Society, vol. 33, no. 3, pp. 386-390, 2005.

[58] P. K. Gianchandani, V. Casalegno, F. Smeacetto, and M. Ferraris, "Pressure-less joining of $\mathrm{C} / \mathrm{SiC}$ and $\mathrm{SiC} / \mathrm{SiC}$ by a $\mathrm{MoSi}_{2} / \mathrm{Si}$ composite," International Journal of Applied Ceramic Technology, vol. 14, no. 3, pp. 305-312, 2017.

[59] H. P. Xiong, B. Chen, Y. Pan, H. S. Zhao, and L. Ye, "Joining of $\mathrm{C}_{\mathrm{f}} / \mathrm{SiC}$ composite with a $\mathrm{Cu}-\mathrm{Au}-\mathrm{Pd}-\mathrm{V}$ brazing filler and interfacial reactions," Journal of the European Ceramic Society, vol. 34, no. 6, pp. 1481-1486, 2014.

[60] H. P. Xiong, B. Chen, W. Mao, and X. H. Li, "Joining of $\mathrm{C}_{\mathrm{f}} /$ $\mathrm{SiC}$ composite with $\mathrm{Pd}-\mathrm{Co}-\mathrm{V}$ brazing filler," Welding in the World, vol. 56, no. 1-2, pp. 76-80, 2012.

[61] H. P. Xiong, B. Chen, Y. Pan, W. Mao, and Y. Y. Cheng, "Interfacial reactions and joining characteristics of a Cu-PdV system filler alloy with $\mathrm{C}_{\mathrm{f}} / \mathrm{SiC}$ composite," Ceramics International, vol. 40, no. 6, pp. 7857-7863, 2014.

[62] E. S. Karakozov, G. V. Konyushkov, and R. A. Musin, "Fundamentals of welding metals to ceramic materials," Welding International, vol. 7, no. 12, pp. 991-996, 1993.

[63] M. W. Barsoum, T. El-Raghy, C. J. Rawn et al., "Thermal properties of $\mathrm{Ti}_{3} \mathrm{SiC}_{2}$," Journal of Physics and Chemistry of Solids, vol. 60, no. 4, pp. 429-439, 1999.

[64] H. L. Liu, C. Y. Tian, and M. Z. Wu, "Technique of joining of $\mathrm{Cf} / \mathrm{SiC}$ composite via preceramic silicone polysilazane and joining properties," Chinese Journal of Nonferrous Metals, vol. 18, no. 2, pp. 278-281, 2008.

[65] B. Zhao, T. Y. Yu, W. F. Ding, and X. Y. Li, "Effects of pore structure and distribution on strength of porous $\mathrm{Cu}-\mathrm{Sn}-\mathrm{Ti}$ alumina composites," Chinese Journal of Aeronautics, vol. 30, no. 6, pp. 2004-2015, 2017.

[66] W. F. Ding, C. W. Dai, Y. Tian, J. H. Xu, and Y. C. Fu, "Grinding performance of textured monolayer CBN wheels: undeformed chip thickness nonuniformity modeling and ground surface topography prediction," International Journal of Machine Tools and Manufacture, vol. 122, pp. 66-80, 2017.

[67] Y. J. Zhu, W. F. Ding, T. Y. Yu et al., "Investigation on stress distribution and wear behavior of brazed polycrystalline cubic boron nitride superabrasive grains: numerical simulation and experimental study," Wear, vol. 376-377, pp. 1234-1244, 2017.

[68] Y. J. Lu, X. Y. Zhang, J. X. Chu, X. Liu, and Z. Fang, "Study on active reactive brazing of $\mathrm{C} \mathrm{SiC} \mathrm{ceramic} \mathrm{to} \mathrm{Nb}$ alloy," Chinese Journal of Rare Metals, vol. 32, no. 5, pp. 636-640, 2008.
[69] C. Y. Liang, Y. G. Du, W. J. Zhang et al., "Joining of $\mathrm{C}_{\mathrm{f}} / \mathrm{SiC}$ composites with Niobium alloy," Aerospace Materials and Technology, vol. 39, no. 3, pp. 45-48, 2009.

[70] J. J. Zhang, S. J. Li, H. P. Duan, and Y. Zhang, "Joining of $\mathrm{C}_{\mathrm{f}} /$ $\mathrm{SiC}$ to Ni-based superalloy with $\mathrm{Zr} / \mathrm{Ta}$ composite interlayers by hot-pressing diffusion welding," Rare Metal Materials and Engineering, vol. 31, no. s1, pp. 393-396, 2002.

[71] Z. W. Yang, L. X. Zhang, X. Y. Tian et al., "Interfacial microstructure and mechanical properties of $\mathrm{TiAl}$ and $\mathrm{C}_{\mathrm{f}} / \mathrm{SiC}$ joint brazed with $\mathrm{TiH}_{2}$-Ni-B brazing powder," Materials characterization, vol. 79, pp. 52-59, 2013.

[72] Z. W. Yang, P. He, and J. C. Feng, "Microstructural evolution and mechanical properties of the joint of TiAl alloys and C/ $\mathrm{SiC}$ composites vacuum brazed with $\mathrm{Ag}$-Cu filler metal," Materials Characterization, vol. 62, no. 9, pp. 825-832, 2011.

[73] Z. H. Zhong, T. Hinoki, H.-C. Jung, Y. H. Park, and A. Kohyama, "Microstructure and mechanical properties of diffusion bonded SiC/steel joint using W/Ni interlayer," Materials and Design, vol. 31, no. 3, pp. 1070-1076, 2010.

[74] Y. J. Li, Selection of Welding Materials, Chemical Industry Press, Beijing, China, 2004.

[75] B. Riccardi, C. A. Nannetti, T. Petrisor, and M. Sacchetti, "Low activation brazing materials and techniques for $\mathrm{SiC}_{\mathrm{f}}$ SiC composites," Journal of Nuclear Materials, vol. 307, pp. 1237-1241, 2002.

[76] H. J. Liu, J. C. Feng, and Y. Y. Qian, "Microstructure and strength of the SiC/TiAl joint brazed with Ag-Cu-Ti filler metal," Journal of Materials Science Letters, vol. 19, no. 14, pp. 1241-1242, 2000.

[77] M. Singh, R. Asthana, and T. P. Shpargel, "Brazing of ceramic-matrix composites to $\mathrm{Ti}$ and Hastealloy using $\mathrm{Ni}$ base metallic glass interlayers," Materials Science and Engineering: A, vol. 498, no. 1, pp. 19-30, 2008.

[78] Y. M. He, J. Zhang, X. Wang, and Y. Sun, "Effect of brazing temperature on microstructure and mechanical properties of $\mathrm{Si}_{3} \mathrm{~N}_{4} / \mathrm{Si}_{3} \mathrm{~N}_{4}$ joints brazed with Ag-Cu-Ti + Mo composite filler," Journal of Materials Science, vol. 8, pp. 2796-2804, 2010.

[79] Y. H. Ban, J. H. Huang, H. Zhang et al., "Microstructure of reactive composite brazing joints of $\mathrm{C}_{\mathrm{f}} / \mathrm{SiC}$ composite to Ti6Al-4V alloy with $\mathrm{Cu}-\mathrm{Ti}-\mathrm{C}$ filler material," Rare Metal Materials and Engineering, vol. 38, no. 4, pp. 713-716, 2009.

[80] X. R. Song, H. J. Li, V. Casalegno et al., "Microstructure and mechanical properties of $\mathrm{C} / \mathrm{C}$ composite/Ti6Al4V joints with a $\mathrm{Cu} / \mathrm{TiCuZrNi}$ composite brazing alloy," Ceramics International, vol. 42, no. 5, pp. 6347-6354, 2016.

[81] Q. Y. Tong, Microstructure and Properties of the On-Line Liquid Infiltrate Joining of $C_{f} / S i C$ Dissertation for Ph.D. thesis, Northwestern Polytechnical University, Xi'an, China, 2003.

[82] Q. Q. Ke, L. F. Cheng, Q. Y. Tong et al., "Joining methods for continuous fiber reinforced ceramic matrix composites," Materials Engineering, vol. 11, pp. 58-63, 2005.

[83] J. Wang, K. Z. Li, W. Li et al., "The preparation and mechanical properties of carbon/carbon composite joints using Ti-Si-SiC-C filler as interlayer," Materials Science and Engineering: A, vol. 574, pp. 37-45, 2013.

[84] Q. Y. Tong, L. F. Cheng, and L. T. Zhang, "Liquid infiltration joining of $\mathrm{C} / \mathrm{SiC}$ and $\mathrm{Nb}$," Journal of Aeronautical Materials, vol. 24, no. 1, pp. 54-56, 2004.

[85] Q. Q. Ke, L. F. Chen, Q. Y. Tong et al., "Microstructure and properties of joints of $2 \mathrm{D} \mathrm{C} / \mathrm{SiC}$ composites by riveting," Rare Metal Materials and Engineering, vol. 35, no. 9, p. 1497, 2006. 
[86] V. L. Lanin, "Ultrasonic soldering in electronics," Ultrasonics Sonochemistry, vol. 8, no. 4, pp. 379-385, 2001.

[87] W. W. Zhao, J. C. Yan, W. Yang, and S. Q. Yang, "Capillary filling process during ultrasonically brazing of aluminium matrix composites," Science and Technology of Welding and Joining, vol. 13, no. 1, pp. 66-69, 2008.

[88] M. Naka and M. Maeda, "Application of ultrasound on joining of ceramics to metals," Engineering Fracture Mechanics, vol. 40, no. 4-5, pp. 951-956, 1991.

[89] M. H. El-Sayed and M. Naka, "Structure and properties of carbon steel-aluminium dissimilar joints," Science and Technology of Welding and Joining, vol. 10, no. 1, pp. 27-31, 2005.

[90] M. H. El-Sayed, K. M. Hafez, and M. Naka, "Interfacial structure and bond strength of ultrasonic brazed Al-304 stainless steel dissimilar joints," Science and Technology of Welding and Joining, vol. 9, no. 6, pp. 560-564, 2004.

[91] X. G. Chen, J. C. Yan, S. C. Ren, J Wei, and Q. Wang, "Ultrasonic-assisted brazing of $\mathrm{SiC}$ ceramic to Ti-6Al-4V alloy using a novel AlSnSiZnMg filler metal," Materials Letters, vol. 105, pp. 120-123, 2013.

[92] X. G. Chen, R. S. Xie, Z. W. Lai et al., "Interfacial structure and formation mechanism of ultrasonic-assisted brazed joint of SiC ceramics with $\mathrm{Al} 12 \mathrm{Si}$ filler metals in air," Journal of Materials Science and Technology, vol. 33, no. 5, pp. 492-498, 2017.

[93] M. C. Halbig, R. Asthana, and M. Singh, "Diffusion bonding of $\mathrm{SiC}$ fiber-bonded ceramics using $\mathrm{Ti} / \mathrm{Mo}$ and $\mathrm{Ti} / \mathrm{Cu}$ interlayers," Ceramics International, vol. 41, no. 2, pp. 2140 2149, 2015.

[94] J. K. Liu, J. Cao, X. G. Song, Y. Wang, and J. C. Feng, "Evaluation on diffusion bonded joints of TiAl alloy to $\mathrm{Ti}_{3} \mathrm{SiC}_{2}$ ceramic with and without $\mathrm{Ni}$ interlayer: interfacial microstructure and mechanical properties," Materials and Design, vol. 57, pp. 592-597, 2014.

[95] J. Cao, J. K. Liu, X. G. Song, X. Lin, and J. C. Feng, "Diffusion bonding of TiAl intermetallic and $\mathrm{Ti}_{3} \mathrm{AlC}_{2}$ ceramic: Interfacial microstructure and joining properties," Materials and Design, vol. 56, pp. 115-121, 2014.

[96] J. S. Varsanik and J. J. Bernstein, "Voltage-assisted polymer wafer bonding," Journal of Micromechanics and Microengineering, vol. 22, no. 2, article 025004, 2012.

[97] C. R. Liu, J. F. Zhao, X. Y. Lu et al., "Field-assisted diffusion bonding and bond characterization of glass to aluminum," Journal of Materials Science, vol. 43, no. 15, pp. 5076-5082, 2008.

[98] Q. Wang, Q. H. Li, D. L. Sun, X. Han, and Q. Tian, "Microstructure and mechanical properties of $\mathrm{SiC} / \mathrm{Ti}$ diffusion bonding joints under electric field," Rare Metal and Materials, vol. 45, no. 7, pp. 1749-1754, 2016.

[99] T. Okuni, Y. Miyamoto, H. Abe, and M. Naito, "Joining of silicon carbide and graphite by spark plasma sintering," Ceramics International, vol. 40, no. 1, pp. 1359-1363, 2014.

[100] R. Pan, Q. Wang, D. L. Sun, and P. He, "Effects of electric field on interfacial microstructure and shear strength of diffusion bonded $\alpha-\mathrm{Al}_{2} \mathrm{O}_{3}$ /Ti joints," Journal of the European Ceramic Society, vol. 35, no. 1, pp. 219-226, 2015.

[101] X. B. Zhou, H. Yang, F. Y. Chen et al., "Joining of carbon fiber reinforced carbon composites with $\mathrm{Ti}_{3} \mathrm{SiC}_{2}$ tape film by electric field assisted sintering technique," Carbon, vol. 102, pp. 106-115, 2016.

[102] T. El-Raghy, M. W. Barsoum, A. Zavaliangos, and S. R. Kalidindi, "Processing and mechanical properties of $\mathrm{Ti}_{3} \mathrm{SiC}_{2}: \mathrm{II}$, effect of grain size and deformation temperature,"
Journal of the American Ceramic Society, vol. 82, no. 10, pp. 2855-2860, 1999.

[103] X. M. Fan, X. W. Yin, Y. Z. Ma, L. Zhang, and L. Cheng, "Oxidation behavior of $\mathrm{C} / \mathrm{SiC}-\mathrm{Ti}_{3} \mathrm{SiC}_{2}$ at $800-1300^{\circ} \mathrm{C}$ in air," Journal of the European Ceramic Society, vol. 36, pp. 24272433, 2016.

[104] D. Yu, L. Y. Cao, and X. L. Dong, "Effects of pulse field on solution microstructure and solution technique of $\mathrm{Al}-4 \% \mathrm{Cu}$ alloy," Material and Heart Treatment, vol. 39, no. 2, pp. 144-146, 2010. 


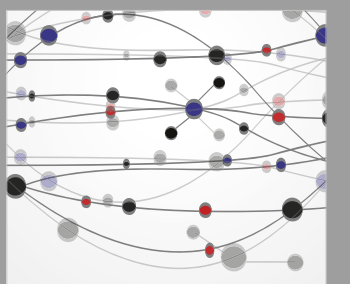

The Scientific World Journal
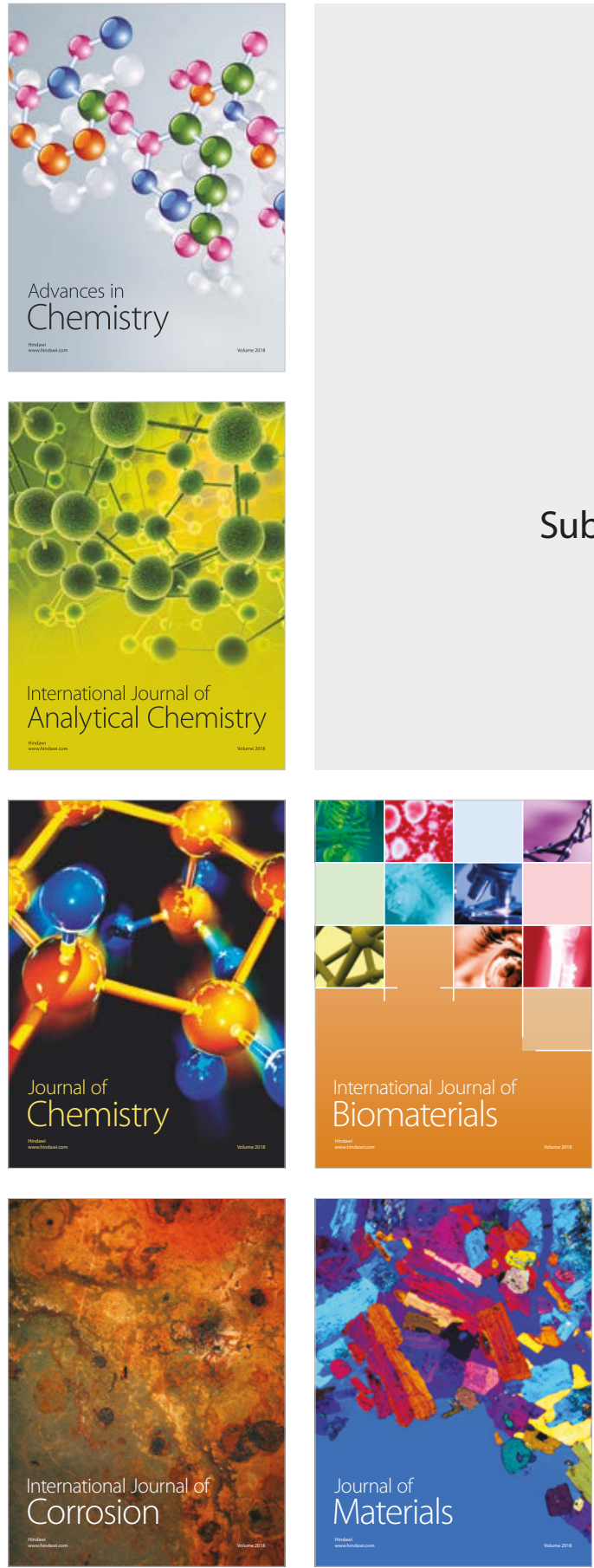

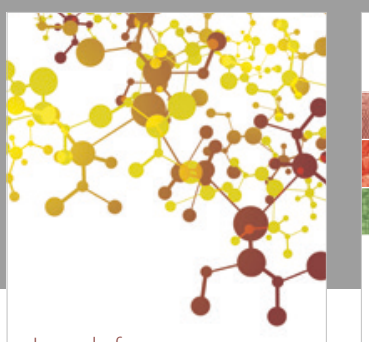

Journal of

Applied Chemistry
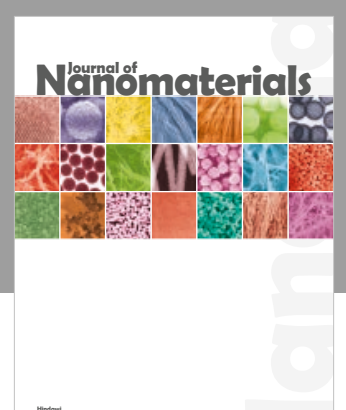

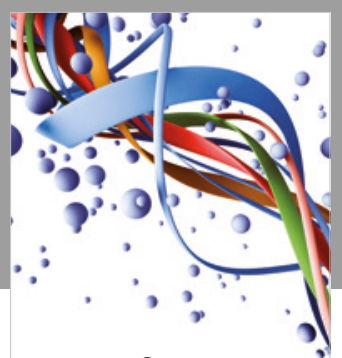

Scientifica

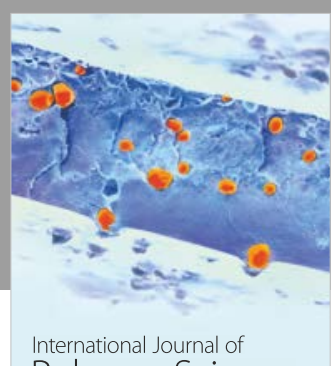

Polymer Science

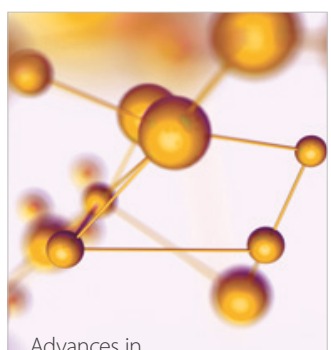

Physical Chemistry
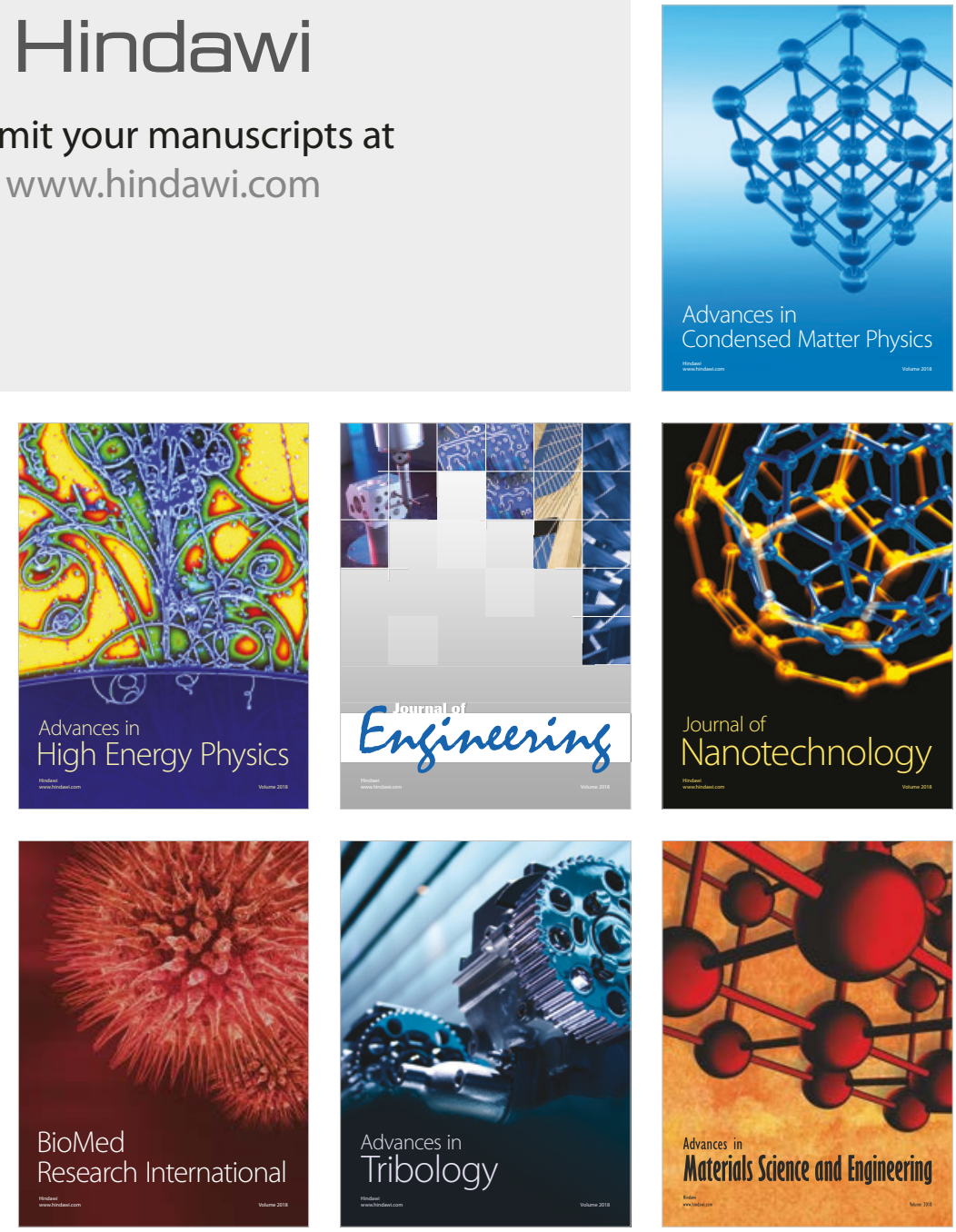